Please cite this article as: S. Domjan, C. Arkar, Ž. Begelj, S. Medved: Evolution of all-glass nearly Zero Energy Buildings with respect to the local climate and free-cooling techniques, Building and Environment 160 (2019) https://doi.org/10.1016/j.buildenv.2019.106183

NOTE: This is a PDF file of an unedited manuscript that has been accepted for publication to Building and Environment. Therefore, the information contained in this manuscript may change before publication.

\title{
Evolution of all-glass nearly Zero Energy Buildings with respect to the local climate and free-cooling techniques
}

\author{
Suzana Domjan ${ }^{\mathrm{a}, \mathrm{b}}$, Ciril Arkarª ${ }^{\mathrm{a}}$ Žiga Begelja ${ }^{\mathrm{a}}$, Sašo Medved ${ }^{\mathrm{a}}$ \\ ${ }^{a}$ Laboratory for Sustainable Technologies in Buildings, Faculty of Mechanical Engineering, University of \\ Ljubljana \\ ${ }^{b}$ corresponding author: suzana.domjan@fs.uni-lj.si
}

\begin{abstract}
This paper presents research on the nearly Zero Energy Buildings (nZEB) metrics of an all-glass office building with advanced multi-layer six-pane glass and building integrated photovoltaic (BIPV) façade structures in different climate conditions. The study was carried out in the following steps: i) development of a time series model of dynamic thermal response of multi-layer 6-pane glass and BIPV façade structures on the basis of transient computational fluid dynamics simulations, ii) integration of the façade structure dynamic model into the building dynamic model by adapting TRNSYS software code, iii) determination of the final energy balance including heating, cooling, ventilation, lighting, and on-site electricity production, iv) nZEB metrics evaluation considering night-time cooling by ventilation, evaporation cooling and hybrid ventilation of case study office buildings. It is shown that energy need for the cooling of the studied office building is dominant in all considered climate conditions, although it can be decreased up to $23 \%$ in most favourable considered climate conditions by implementing free cooling techniques. The case study buildings with BIPV structures on their east and west façades meet more stringed nZEB criteria; in addition, final energy demand decreases by $17-37 \%$ in comparison to the reference all-glass building. In the case of all-BIPV buildings, the final energy demand is decreased by $36-48 \%$. Such buildings can significantly contribute to the mitigation of global climate change, as BIPV electricity production exceeds the building's energy demand.
\end{abstract}

Keywords: nearly Zero Energy Buildings, multi-layer glass structures, building integrated photovoltaics, computational fluid dynamics, dynamic building thermal response model, natural space cooling

\section{Introduction}

The recast of the Energy Performance Building Directive (EPBD) [1] introduces requirements for nearly Zero Energy Buildings (nZEB). Consequently, EPBD-supporting standards introduce metrics for the evaluation of nZEB criteria [2]. The revised EPBD [3] sets even more ambitious goals to reduce greenhouse gas emissions and emphasises that passive techniques should be applied to reduce energy needs for heating and cooling. D'Agostino and Mazzarella [4] suggest that nZEB requires that thermal and electricity needs should be reduced as much as reasonably possible by improving the thermal properties of the building envelope and increasing the use of solar energy for heating and daylighting and environmental energy for cooling. Elarga et al. [5] conclude that the efficient implementation of renewable energy sources, especially solar energy in the building sector, is vital for nZEB buildings to be sustainable. The study presented by Asdrubaly et al. [6] 
further demonstrated that the shortest energy and environmental payback times are achieved with applied renewable energy generation technologies (e.g., solar thermal and PV).

For several decades, glass buildings have been preferred by architects and their clients because of their aesthetic and technological aspects. Pariafsai [7] presents an overview of design considerations in glass buildings, concluding that advances in research and technology ensure that contemporary glass buildings are increasingly durable, safe, and useful. Several advanced technologies for building glass façade structures have been developed in recent decades to improve the energy efficiency of extended glazed buildings $[8,9]$. Recently, research has focused on advance multi-layer, vacuum, and aerogel glass façade structures [10-13] with highly reduced U-values for nZEB buildings. However, Murano et al. [14] demonstrated that, with increased window-to-wall ratios, space cooling is the most significant challenge for nZEB in southern European climate conditions. The same conclusions can be derived from the study presented by Bruno, [15]; results also showed that in all-glass buildings yearly energy need is the lowest with glazing with the lowest thermal and total solar energy transmittance. In these studies, static numerical models for glazing prevail, leading to a single thermal transmittance value of glazed façade structures and non-transient heat transfer conditions. Lu and Memari [16] published a study on the evaluation of the thermal transmittance of building envelopes, comparing hot-box laboratory methods for the determination of steady-state thermal transmittance. In their study, they show the importance of using dynamic models in case of in-situ measurement conditions for the accuracy of results. Nevertheless, Foucquier et al. [17] and Li and Wen [18] point out that the transient numerical modelling of the thermal response of the buildings requires the transient modelling of all types of façade structures. Buildings with all-glass façades differ from conventional buildings, not only in terms of energy demand but also in the complexity of indoor comfort assessment $[19,20]$. Consequently, the indoor comfort design category [21] has a significant impact on energy demand for the operation of glass buildings. Results of analyses $[19,20]$ have demonstrated that high-quality glazing and shading contributes to reduced energy needs and improved indoor comfort.

Building-integrated photovoltaics (BIPV) has been gaining interest as a mature technology for supporting nZEB requirements. The definition and advantages of BIPV were recently presented in [22-24], in which the authors also pointed out that in the current BIPV market, $80 \%$ of systems are roof integrated, compared to $20 \%$ façade structures; the authors conclude that the BIPV market will proliferate because of the high demand for new and renovated buildings. The overall energy balance, including heating, cooling, and lighting demand for offices with BIPV, is presented in [25] for different climate regions in China. The authors study different constructions of glass-integrated BIPV with extremely high $U$ values (1.6 to $2.6 \mathrm{~W} / \mathrm{m}^{2} \mathrm{~K}$ ); they conclude that energy savings of more than $50 \%$ can be achieved with BIPV.

Natural cooling in combination with hybrid mechanical ventilation is a highly efficient technique that enables significant increases in the energy efficiency of all-glass buildings. Jung et al. [26] recently presented the prototype of a multi-functional smart window with PV blinds and integrated ventilation system that enable distributed on-site electricity generation and energy efficient natural and hybrid ventilation. They established that this solution could contribute toward achieving nZEB requirements of new and existing buildings. Solgi et al. [27] analysed night-time ventilation strategies in buildings, stating that the optimisation of operation is required according to the climate conditions. The optimisation of night-time ventilation cooling of office buildings was analysed by Medved et al. [28] and Vidrih et al. [29]. Another promising technique for natural cooling is evaporative cooling. Porumb et al. [30] published extended research on evaporative cooling techniques, including direct and indirect processes. The experimental efficiency of indirect evaporative cooling was researched by De Antonellis et al. [31], showing that significant cooling capacity can be achieved in many summer-time climate conditions.

According to the preceding literature overview, it can be concluded that this paper presents research innovations in the field of nZEB, built with advanced glass multi-layer façade structures, with or without BIPV. The thermal transmittance of such façade structures is significantly lower in comparison to ordinary glass façade structures and close to the requested values in the majority of national regulations for opaque façade structures. Furthermore, due to high solar irradiation absorption in glass layers and PV cells, the thermal response of such façade structures is transient. In this paper, the method for the characterisation of transient 
heat transfer based on reference transient computational fluid dynamics (CFD) simulation by regression models is proposed, and the procedure for the integration of developed regression models in buildings' dynamic thermal response model is shown. Due to the high cooling demand of all-glass buildings, the efficiency of several techniques of natural cooling has been studied for different climate conditions. Metrics based on the EPBD supporting standard [32] are used for the evaluation of the chosen architecture of the allglass building with advanced multi-layer façade structures.

\section{Advanced multi-layer glass and BIPV façade structures and all-glass building case study}

The purpose of the presented research was to determine whether modern all-glass buildings can be designed to meet the requirements of nearly Zero Energy Buildings as requested in the EPBD recast. All-glass buildings built with two types of advance multi-layer glass façade structures were examined - a six-pane glass structure (Fig.1) and a similar structure upgraded with PV cells laminated inside outer glass pane forming the BIPV structure. It can be concluded that such multi-layer glass structures are the best available technology product on the market [33]; meanwhile, BIPV façade structures are in the development stage and were tested in the framework of on-going research project [34]. Extended technical data of the multi-layer glass façade structure can be found in [35]. In the presented case, the raster of PV cells (156 × $156 \mathrm{~mm}$ [36]) in the BIPV façade structure was selected in such a way that the PV cell area corresponds to $60 \%$ of the total area of the multi-layer glass structure. Such a façade structure enables daylighting and users' view of the exterior and will be noted in the paper as the BIPV 100 façade structure.

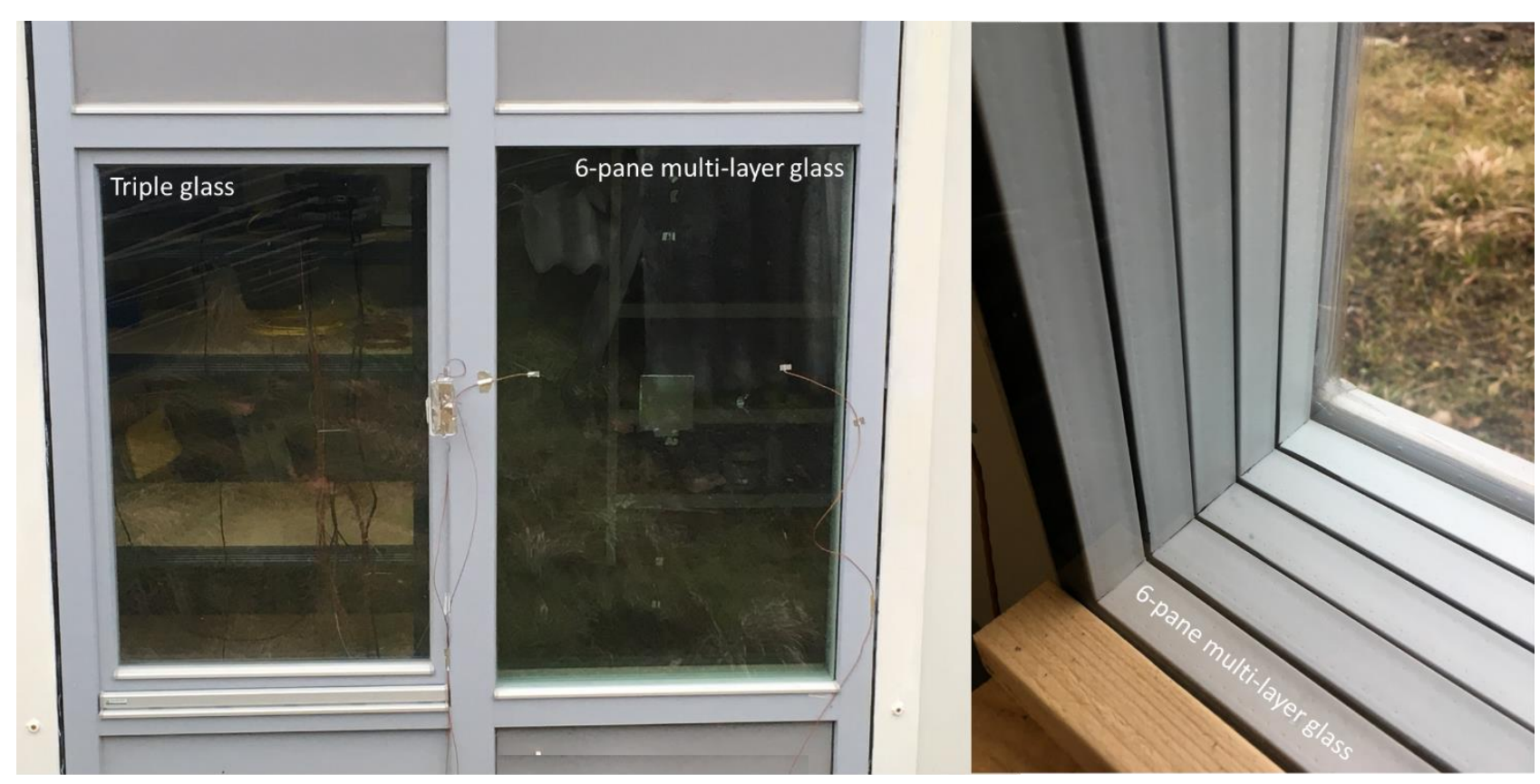

Fig. 1. Multi-layer six-pane glass structure installed on the façade of the temperature controlled test facility during the in-situ validation of dynamic heat transfer model.

The energy efficiency and nZEB requirements were evaluated for mid-floor in the case study office building with a square floor plan $(20 \times 20 \mathrm{~m})$ and floor area $A_{u} 400 \mathrm{~m}^{2}$. The façades are $4 \mathrm{~m}$ high, and the floor has an open height of $3.75 \mathrm{~m}$. In the core of the office, a communication corridor $(3 \times 6 \mathrm{~m})$ with concrete walls is built. Reference conditions (indoor temperature, ventilation rate, average illuminance) and schedules (occupants, appliances, lighting) of building operation were taken from [37] assuming Category No. Of-1 type of the building.

\section{Dynamic response models of multi-layer glass and the BIPV $_{100}$ façade structure}

To evaluate yearly nZEB metrics of a building built with advanced glass and BIPV façade structures on the hourly time steps, dynamic response models of the considered structures were developed in the first step 
and integrated into the building dynamic thermal response numerical model in the second step. The first step procedure is shown in Fig. 2; it consists of the determination of static thermal and radiative properties of structures, CFD 2D transient numerical simulations that were used for forming the dynamic thermal response regression model for the prediction of combined specific convective and longwave radiation heat flux at inner surface of the multi-layer glass and BIPV structures $\dot{\mathrm{q}}_{i}(\mathrm{t})\left(\mathrm{W} / \mathrm{m}^{2}\right)$, a model of transmitted shortwave solar irradiation $\dot{\mathrm{q}}_{\mathrm{s}}(\mathrm{t})\left(\mathrm{W} / \mathrm{m}^{2}\right)$, and model of specific electrical power in case of BIPV ${ }_{100}$ façade structures $\dot{e}_{\mathrm{PV}}(\mathrm{t})$ $\left(\mathrm{W} / \mathrm{m}^{2}\right)$.

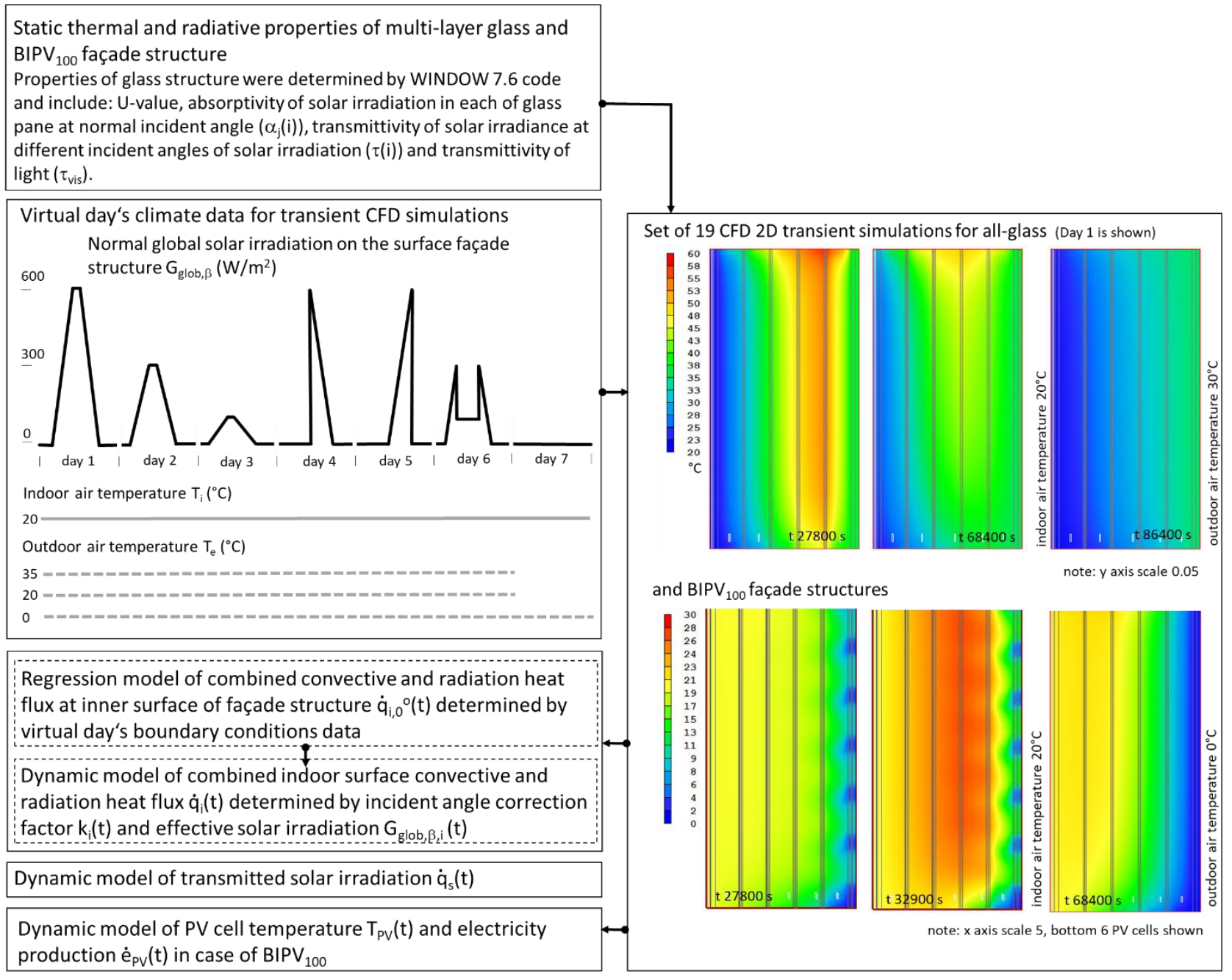

Fig. 2. Schematic description of the procedure developed for the determination of dynamic response models of all-glass and $\mathrm{BIPV}_{100}$ façade structures.

The reason for such an approach is the high thermal mass of the multi-layer glass structure and the high accumulation of solar irradiation in the outer glass pane in the case of the BIPV 100 façade structure. Consequently, the heat flux at the inner surface of the structure decreases during the daytime and has an observable time delay. The impact of heat accumulation was observed in the lower thermal transmittance of such structures during the night-time, by numerical modelling and in-situ experiments [11]. Furthermore, the proposed procedure can be used, for example, for the developing of dynamic response models for BIPV structures in any architectural form of PV cell layout, for glass envelope structures with natural or forced ventilated gaps, advanced glass façade structures with integrated PCM inserts, or glass structures with adaptive optical properties. The procedure is presented in detail in [11].

The static thermal and radiative properties of the studied multi-layer glass were determined using WINDOW 7.6 software [38] and validated with in-situ experiments on a façade structure $1.2 \mathrm{~m}$ high and $0.8 \mathrm{~m}$ wide (Fig. 1) including validation of thermal transmittance (U-value) and solar irradiation transmittance [11]. PHOENICS 2018 [39] CFD software was used for transient heat transfer numerical simulations. 2D numerical 
simulations were performed due to the time rationality and because 3D simulations shows no significant impact of spacers' heat bridges on the average heat flux at inner surface $\dot{\mathrm{q}}_{i}(\mathrm{t})$. The same was found for the case of replacing the chessboard layout of PV cells with adequate 2D strips. For each of the seven virtual days, transient CFD simulations were repeated, assuming different global solar irradiation $G_{g l o b, \beta}\left(W / m^{2}\right)$ scenarios, three constant outdoor air temperatures $\mathrm{T}_{\mathrm{e}}\left({ }^{\circ} \mathrm{C}\right)$ and constant indoor air temperature $\mathrm{T}_{\mathrm{i}}\left({ }^{\circ} \mathrm{C}\right)$ scenarios (Fig. 2). As global solar irradiation defined by virtual days, is taken as normal to the surface of the structure, the absorptivity of solar irradiation in glass panes at normal incident angle $\left(i=0^{\circ}\right)$ determined by WINDOW 7.6. was taken into account for each of the glass panes at any simulation time $t$ to define in-glass heat flux sources. Transient heat flux sources were defined as In-Form equations [39]. In the case of BIPV $V_{100 \text {, }}$ the absorptivity of integrated PV cells equalling 0.75 was assumed, taking into account half width outer glass transmittivity (0.96), the absorptivity of the PV cell surface (0.95), and the share of solar irradiation converted to heat $\left(1-\eta_{\mathrm{PV}}=0.82\right)$ [36]. At the indoor and outdoor structure surfaces, the combined heat transfer coefficients were taken from [40] bi bil 40 ISO6946. Bouncy driven flow was assumed, and the IMMERSOL radiation model was used for the determination of radiation heat transfer between the glass panes. Using CFD data, a regression model of combined specific convective and radiative heat flux $\dot{\mathrm{q}}_{\mathrm{i}, 0^{0}}(\mathrm{t})\left(\mathrm{W} / \mathrm{m}^{2}\right)$ on the indoor surface of the structure was developed in the form of:

$$
\dot{\mathrm{q}}_{\mathrm{i}, 0^{0}}(\mathrm{t})=\sum_{\mathrm{k}=1}^{2} \sum_{\mathrm{j}=0}^{\mathrm{m}}\left(\mathrm{a}_{\mathrm{k}, \mathrm{t}-\mathrm{j}} \cdot \mathrm{x}_{\mathrm{k}, \mathrm{t}-\mathrm{j}}\right)+\mathrm{b} \quad\left(\mathrm{W} / \mathrm{m}^{2}\right)
$$

where $k$ is the number of involved independent variables $x, j$ is the hour interval from present time $(t=0)$ to the past time $(t-m)$, a are regression model coefficients, and $b$ is biased. Two independent variables: global solar irradiation normal to the surface $\left(i=0^{\circ}\right) G_{\text {glob, } \beta}(t)\left(W / \mathrm{m}^{2}\right)$ and the difference in indoor and outdoor air temperature $\Delta \mathrm{T}=\mathrm{T}_{\mathrm{i}}-\mathrm{T}_{\mathrm{e}}\left({ }^{\circ} \mathrm{C}\right)$ were included in the regression model. The values of coefficients in regression modes for the six-pane glass and $\mathrm{BIPV}_{100}$ façade structures are shown in Appendix A. A set of additional CFD transient simulations was done using the boundary condition data presented in Figure 2, and in-glass heat flux sources taking into account the solar irradiation absorptivity of each glass pane at different incident angles of solar irradiation $\left(15^{\circ}, 30^{\circ}, 45^{\circ}\right.$, and $\left.75^{\circ}\right)$. The data were used for forming the regression model of the incident angle correction factor $\mathrm{k}_{\mathrm{qi}}(\mathrm{i})(-)$. This factor is used to for determination of equivalent solar irradiation on surface of façade structure $G_{\text {glob, } \beta, I}\left(W / \mathrm{m}^{2}\right)$ that is used in Eq.1. for calculation of the actual total heat flux at inner surface of multi-layer glass or BIPV façade structure $\dot{q}_{i}(t)\left(W / m^{2}\right)$ at current incident angle of solar irradiation (Appendix B).

Transmitted solar irradiation $\dot{\mathrm{q}}_{\mathrm{s}}(\mathrm{t})$ is determined by dividing global irradiation into direct and diffuse irradiation. Transmissivity of solar irradiation of the all-glass structure was determined with WINDOW 7.6. software. The transmissivity of the direct solar irradiation of the all-glass structure was approximated according to the incident angle [11]. For diffuse irradiation, transmissivity is calculated at an incident angle of $55^{\circ}$ using the same approximation model. Diffuse irradiation was increased by ground reflected irradiation, and albedo of 0.2 was taken into account as typical urban environment value. The transmissivity of solar irradiation of the $\mathrm{BIPV}_{100}$ structure was decreased proportional to the transparent area of the façade structure (in the case of BIPV 100 by a factor of 0.4).

A model of BIPV $_{100}$ structure electrical power $\dot{\mathrm{e}}_{\mathrm{PV}}$ was developed, taking into account the reference efficiency of PV solar cells $\left(\eta_{\mathrm{PV}, \mathrm{P}}=18 \%\right.$ in case study [36]) and two correction factors: the PV cell temperature (determined by regression model, developed on the base of the CFD simulation) and solar irradiation correction factor, which take into account the decrease of PV cell efficiency at lower solar irradiation $(<200$ $\mathrm{W} / \mathrm{m}^{2}$ ). The model is presented in detail in [11].

\section{Dynamic model of natural cooling techniques}

Previous research studies $[14,15]$ have shown that the energy demand for cooling of all-glass buildings has the largest share in total energy needs regardless of the climate. BIPV façade structures could significantly decrease energy demand for cooling; nevertheless, there is still high potential for increasing energy efficiency 
with techniques of natural cooling. In this paper, three such techniques will be analysed: cooling by nighttime ventilation, hybrid ventilation, and indirect evaporative cooling of supply air for ventilation of the building. Control algorithms for all three techniques was developed and integrated into TRNSYS 17.2 [41] simulation tool.

Cooling by night-time ventilation was analysed, taking into account the size of the opening of the façade structures created by tilting façade elements, which enables natural ventilation through bottom-hung inward openings. Opening of the structures is controlled according to the algorithm shown in Figure 3 (left). In all cases, it is assumed that each façade structure element that can be opened is $3 \mathrm{~m}$ high and $1.2 \mathrm{~m}$ wide. By default, the façade structure's area in the total size of $20 \%$ of floor area is openable. Minimum and maximum tilt angles are defined as a design parameter, by default as $2^{\circ} / 10^{\circ}$. Single-side room ventilation model was assumed for determination of volume air flow rate $\dot{V}_{\text {inf }}\left(\mathrm{m}^{3} / \mathrm{h}\right)$ and integrated, together with control algorithm, into TRNSYS simulation tool. Airflow was treated as infiltration, and the total area of the ventilation opening was defined by the total area of opened façade structures and tilted angle coefficient $c_{k}(\alpha)$ as defined in [42]. The relevant equations are shown in Appendix C. According to the occupancy schedule, mechanical ventilation does not operate during night-time cooling, and mechanical cooling is also switched off. Figure 4 (left) shows TRNSYS simulation results of indoor air temperatures and air exchange rates for a selected summer week in the case study building. It can be concluded that the algorithm is adequate as windows are closed at $\mathrm{T}_{\mathrm{e}}$ below $12^{\circ} \mathrm{C}$ and $\mathrm{T}_{\mathrm{i}}$ is not below $18^{\circ} \mathrm{C}$ as it is set in the control algorithm. Infiltration rate $\mathrm{n}$ up to $6 \mathrm{~h}^{-1}$ was obtained. Meteorological data from TRY of Ljubljana was used.

\begin{tabular}{|c|c|}
\hline \multicolumn{2}{|c|}{$\begin{array}{l}\text { Area of openable façade structures expressed as } \% \text { of } \\
\text { floor area. } \\
\text { common } 5 \% \text { to } 20 \%\end{array}$} \\
\hline $\begin{array}{l}\text { Façade } \\
\text { structures } \\
\text { are closed }\end{array}$ & $\begin{array}{l}T_{e}<=12^{\circ} \mathrm{C} \text { and } T_{i}<=18^{\circ} \mathrm{C} \\
\text { to avoid thermal discomfort } \\
\text { and } T_{i}-T_{e}<=1{ }^{\circ} \mathrm{C} \\
\text { set as hysteresis lower level to avoid rapid ON/OFF } \\
\text { process }\end{array}$ \\
\hline $\begin{array}{l}\text { Façade } \\
\text { structures } \\
\text { are opened }\end{array}$ & $\begin{array}{l}T_{i}>18^{\circ} \mathrm{C} \text { and } T_{i}-T_{e}>4^{\circ} \mathrm{C} \\
\text { to ensure efficient cooling by ventilation } \\
\qquad \begin{array}{l}\alpha=\min \text { if } T_{e}>18^{\circ} \mathrm{C} ; \\
\alpha=\max \text { if } T_{e}>=22^{\circ} \mathrm{C}\end{array} \\
\text { In between linear approximation of tilt angle } \alpha \text {; to avoid } \\
\text { rapid ON/OFF process; note for night-time cooling } \alpha \text { is } \\
\text { always set to maximum value between 1:00 and } 6: 00 \\
\text { o'clock }\end{array}$ \\
\hline
\end{tabular}

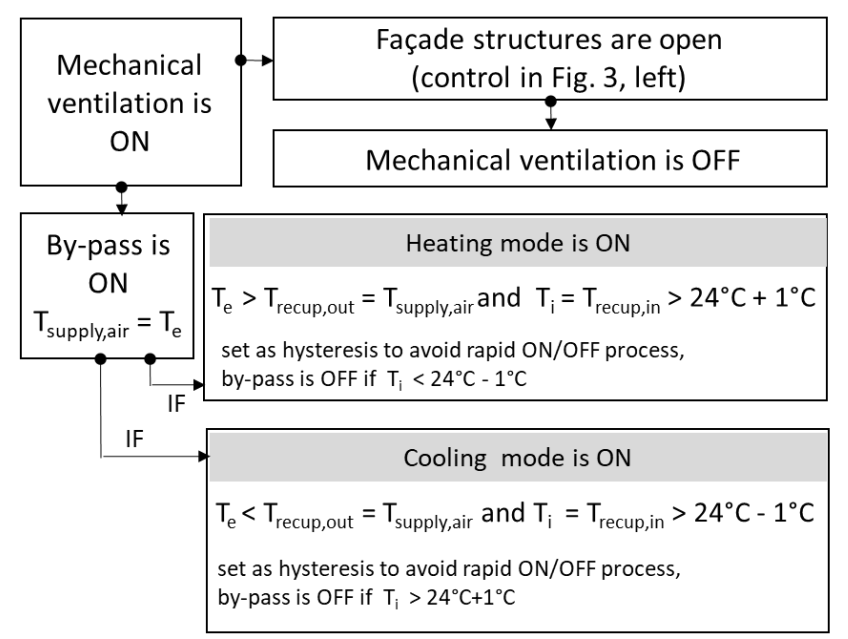

Fig. 3. Control algorithm for opening of the façade structures enabling night-time cooling by ventilation (left) and control algorithm for day-time hybrid ventilation (right).

The numerical model of cooling by natural night-time ventilation was validated with an in-situ experiment between July $30^{\text {th }}$ and August $3^{\text {th }} 2018$ in an apartment in a multi-family residential building. The apartment was ventilated by two west-orientated bottom-hung tilted windows with a height of $2.5 \mathrm{~m}$ and $0.9 \mathrm{~m}$ width. The apartment has a useful (floor) area of $10.4 \mathrm{~m}^{2}$, and its depth is $\sim 1.5$ times the room height. During the experiment, both windows were opened between 7 p.m. and 7 a.m. To emphasise the impact of cooling by night-time ventilation, outdoor shades were not used during the experiments, and the mechanical ventilation system was turned off. From Figure 4 (middle), it can be seen that measured ( $T_{\text {experiment }}$ ) and modelled ( $\left.T_{\text {model }}\right)$ indoor air temperature are in good agreement.

Hybrid ventilation is treated as an upgraded night-time natural ventilation technique, allowing buildings also to be naturally ventilated during occupied (working) hours. In this way, not only energy needs for cooling but also auxiliary energy for the operation of the mechanical ventilation system decreases. During the naturally ventilated period, the mechanical ventilation system is turned off. As part of hybrid ventilation control, an air-handling unit operates in a by-pass mode according to the control algorithm shown in Figure 3 (right). 
In the presented study, the indirect evaporative cooling of supply air in a heat recovery unit by humidification of the extract air was analysed as a natural cooling technique. The direct evaporative cooling of supply air will be more efficient but could be used only in very dry climate conditions to avoid uncomfortable indoor air humidity. It is assumed that indirect evaporative cooling is enabled only during cooling periods, that a mechanical ventilation system is in operation, and that the maximum relative air humidity of evaporatively cooled extract air is controlled to not exceed $80 \%$ of relative humidity at the exit of the heat recovery unit. Figure 4 (right) shows the results of the simulation model presenting the supply air temperature $T_{\text {supply, }}$ outdoor $T_{e}$ and indoor $T_{i}$ air temperatures and air exchange rates $n$ provided by mechanical ventilation system, in the case of indirect evaporative cooling of the all-glass case study building during a selected summer week.
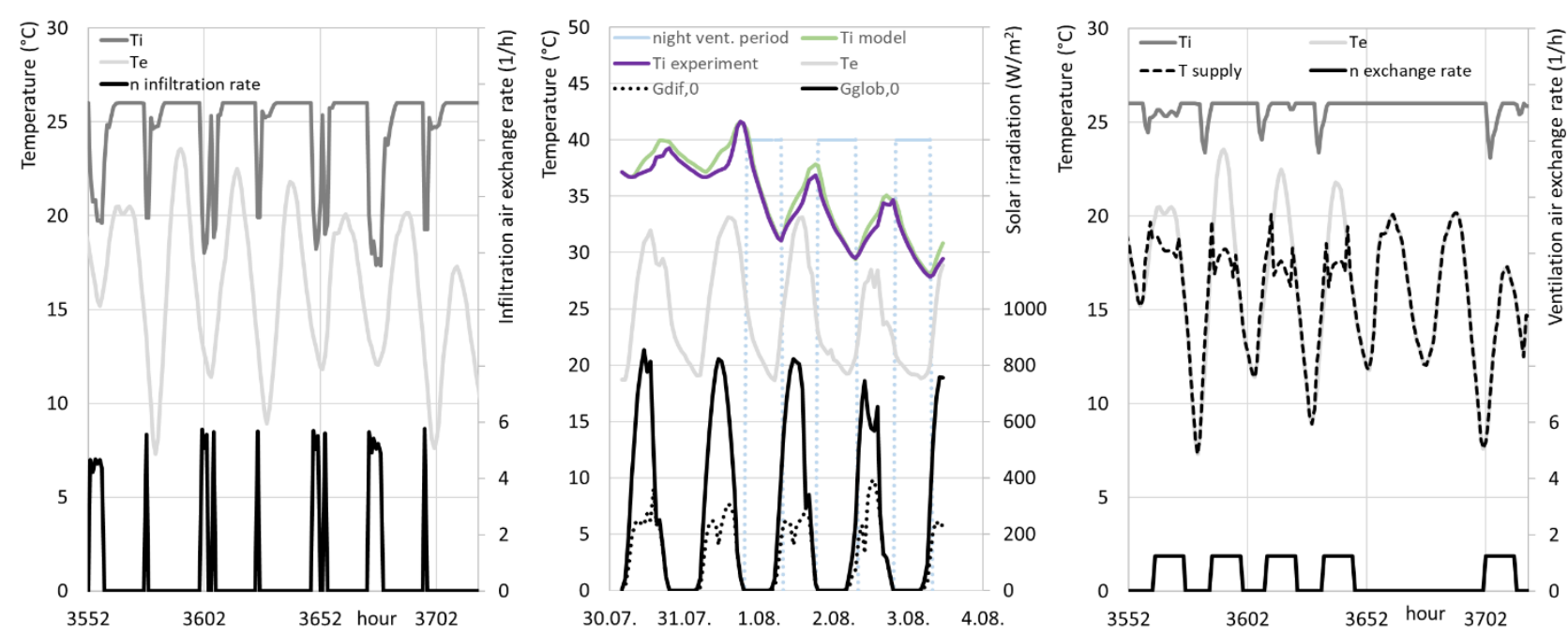

Fig. 4. Thermal response and infiltration air exchange rate of natural ventilated case study all-glass building during selected summer week (left); in-situ validation of natural cooling by ventilation numerical control algorithm (middle), temperature of supply air $\mathrm{T}_{\text {supply }}$ cooled by indirect evaporative cooling process (right) as modelled with TRNSYS simulation tool.

\section{Energy needs and final energy demand modelling}

Energy needs and final energy demand for heating, cooling, mechanical ventilation, and lighting were modelled using the TRNSYS 17.2 [41] simulation tool upgraded with developed regression models and control algorithms. The procedure for the determination of energy needs for heating $Q_{N H}$ and cooling $Q_{N C}$ is based on the dynamic models of $\dot{\mathrm{q}}_{\mathrm{i}}(\mathrm{t})$ and $\dot{\mathrm{q}}_{\mathrm{s}}(\mathrm{t})$ of each multi-layer glass or BIPV 100 façade structures, integrated into the thermal response model of the building (Type 56), in the way presented in Figure 5 . In the Type 56 unit, multi-layer and BIPV structures are defined as reference glass structures.

With the Type 56 determined values of radiative and convection heat flux at inner surface of such structures as well as transmitted solar irradiation are compared to the values which are calculated in parallel by the regression models within TRNSYS iteration loop. Taking into account the area of these structures, total energy fluxes $\dot{Q}_{i}$ and $\dot{Q}_{s}$ are determined. The difference between with the Type 56 and regression models determined values defines additional convective and radiant heat gain or sink in a building's model within the next interaction at current time step of TRNSYS simulation. In this way the impact of any façade structure design on energy needs for heating and cooling can be determined. 


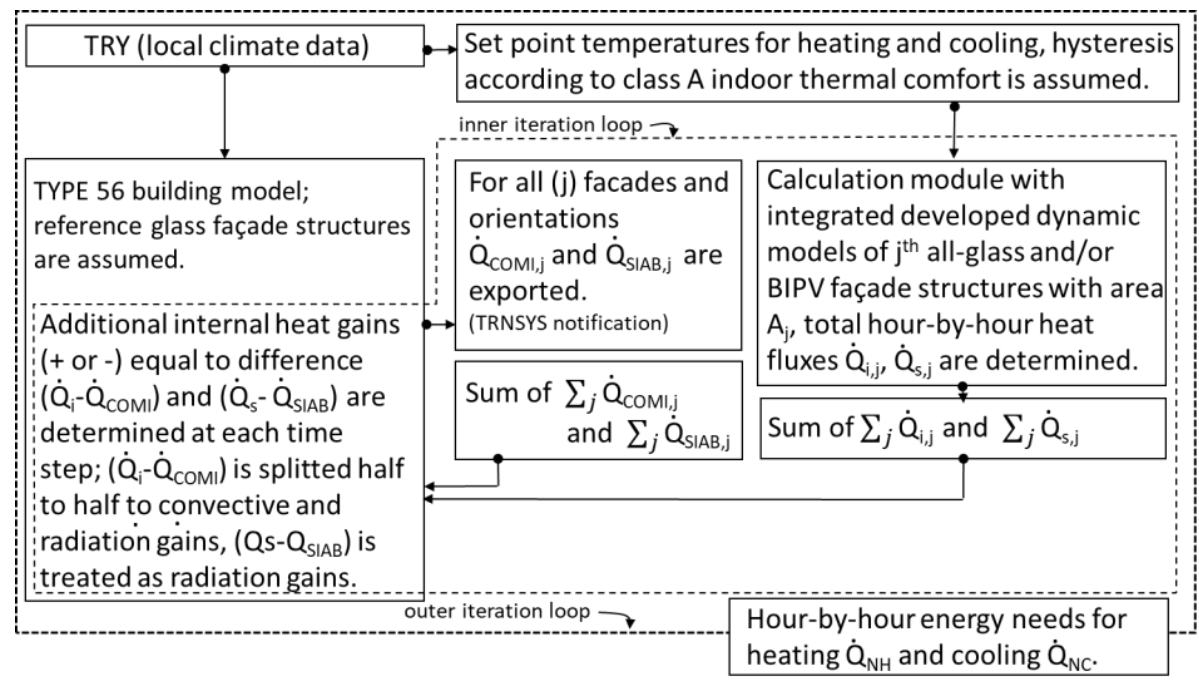

Fig. 5. Procedure for the determination of energy needs for heating $Q_{N H}$ and cooling $Q_{N c}$ with integrated dynamic models of $\dot{\mathrm{q}}_{i}(\mathrm{t})$ and $\dot{\mathrm{q}}_{\mathrm{s}}(\mathrm{t})$ for multi-layer glass and BIPV ${ }_{100}$ façade structures into TRNSYS simulation tool.

On the basis of energy needs, hour-by-hour analysis of final energy demand for heating and cooling is determined. It is assumed that an electrically driven air-water heat pump/cooling engine is used as a heat and cold generator. Hour-by-hour final electricity demand for operation of the heat pump (HP) was calculated by modelling coefficients of performance in heating $\left(\mathrm{COP}_{h}\right)$ and cooling $\left(\mathrm{COP}_{c}\right)$ modes of operation, as presented in Appendix D. A Carnot efficiency $\eta_{\mathrm{h}}$ equal to 0.5 is taken into account for heating mode and $\eta_{\mathrm{c}}$ 0.35 for cooling mode according to a survey of market available products. Due to mathematical consistency, the cooling $\mathrm{COP}_{\mathrm{c}}$ was limited to the value of 8 at low outdoor air temperatures and $\mathrm{COP}_{\mathrm{c}}=12$ was assumed in the case of negative temperature difference conditions, as it was assumed that HP operates in free (passive) cooling mode. In both cases this will only influence the energy demand if building actually needs cooling at that time. Auxiliary energy for the operation of the cooling tower fan, pumps, and controllers was assumed as $25 \%$ of energy demand $[43,44]$ and no impact of reversing valves on energy efficiency is taken into account. The water-heating system design temperature is $50^{\circ} / 40^{\circ} \mathrm{C}$, and the water-cooling system design temperature is $7^{\circ} \mathrm{C} / 12^{\circ} \mathrm{C}$. The water distribution system was modelled according to an empirical expression proposed in [45], taking into account the gross dimensions of office. The linear thermal transmittance of pipes is equal to $0.22 \mathrm{~W} / \mathrm{mK}$ [46]. No heat gains/sinks are assumed for cold water distribution systems. Room temperature is controlled by a PID controller so that the amplitude of the indoor air temperature is below $1.5 \mathrm{~K}$ to fulfil class A of thermal comfort [47].

Meanwhile, energy needs for ventilation are included in energy needs for heating and cooling; the final energy demand for the operation of the ventilation system was determined, taking into account expended specific fan power (SFP), according to [48] for supply and extract air fans. The specific fan power of supply and extract fans according to the category SFP $3\left(2 \times 1000 \mathrm{~W} /\left(\mathrm{m}^{3} / \mathrm{s}\right)\right)$, the additional mechanical filter stage $\left(+300 \mathrm{~W} /\left(\mathrm{m}^{3} / \mathrm{s}\right)\right)$, and heat recovery $\left(+300 \mathrm{~W} /\left(\mathrm{m}^{3} / \mathrm{s}\right)\right)$ were taken into account in case study examples. The fans operate with variable air volume according to the occupancy schedule. The ventilation system has a heat recovery unit with a default temperature efficiency of $85 \%$. The bypass operation of supply air is controlled by the algorithm shown in Figure 3. During non-occupied hours and natural ventilation in hybrid mode, mechanical ventilation is not used. In the study, the energy need for ventilation is assumed to be equal to the final energy demand for ventilation.

The energy need for lighting $\left(Q_{1}\right)$ is determined by dividing the office into a four-metre deep window zone (Zone 1 ) and a remaining inner zone (Zone 2), as presented in Figure 6 (top). The design illuminance $E_{d}$ of a working plane of 750 lux was assumed [37]. Average daylighting factors $\mathrm{DF}_{\mathrm{av}}(\%)$ were determined using IDAICE software [49] at an outdoor horizontal plane illuminance of 5000 lux at CIE overcast sky conditions for each of two zones for the pre-design façade structure configurations of case study buildings. Taking into account the daylight efficiency of global solar irradiation $\mathrm{K}_{\mathrm{s}, \mathrm{glob}}=107 \mathrm{Im} / \mathrm{W}$ [50], the minimum solar irradiation 
at which the recommended illuminance of the working plane will be reached was determined for both zones, as shown in Table 1. If daylight is not sufficient, electrical lights with reference efficiency $\mathrm{K}_{\mathrm{l}}=140 \mathrm{Im} / \mathrm{W}$ are switched on. Control algorithm was integrated into TRNSYS computer code to turn lighting on according to hour-by-hour daylight conditions if actual hourly global solar irradiation $G_{\text {glob,o }}$ is lower that $G_{\text {glob,o,min }}$ (Fig. 6 , bottom).
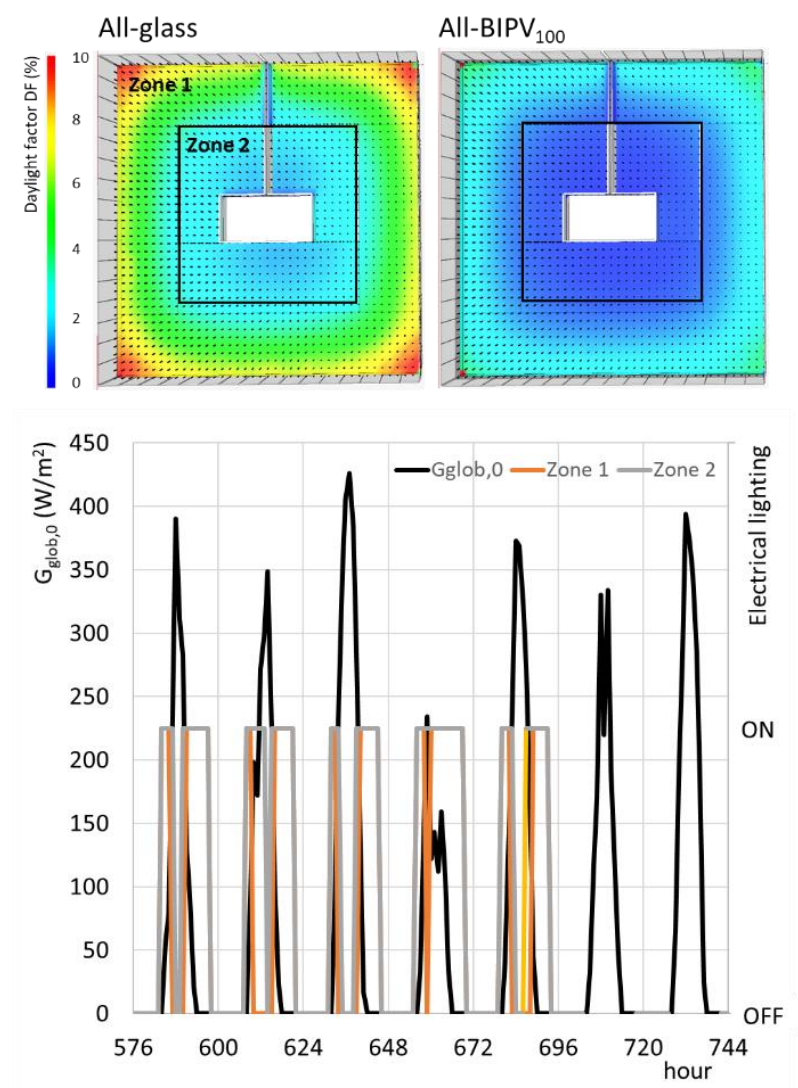

Fig. 6. Daylight factor at working plane in case study building with multi-layer glass and all-BIPV ${ }_{100}$ façade structures installed in all façades (top); switch ON/OFF intervals of electric lighting in Zone 1 and Zone 2 of the case study building during selected week in January (bottom; TRY for Ljubljana [51]).

Table 1. Average $D_{a v}$, minimum outdoor illuminance $E_{e, m i n}$ and corresponding minimum global solar irradiation on the horizontal plane $\mathrm{G}_{\mathrm{glob}, \mathrm{o}, \mathrm{min}}$ at which the required illumination of working plane $(0.8 \mathrm{~m}$ above floor) $E_{d} 750$ lux will be achieved for different configurations of façade structures in both zones in case study building.

\begin{tabular}{|c|c|c|c|c|c|c|}
\hline & \multicolumn{3}{|c|}{ Zone 1} & \multicolumn{3}{|c|}{ Zone 2} \\
\hline$E_{d}=750$ lux & $\begin{array}{c}\mathrm{DF}_{\mathrm{av}, 1} \\
(\%)\end{array}$ & $\begin{array}{c}E_{0, \min , 1} \\
\left(\mathrm{Im} / \mathrm{m}^{2}=\operatorname{lux}\right)\end{array}$ & $\begin{array}{c}\mathrm{G}_{\mathrm{glob}, \mathrm{o}, \min , 1} \\
\left(\mathrm{~W} / \mathrm{m}^{2}\right)\end{array}$ & $\begin{array}{c}\mathrm{DF}_{\mathrm{av}, 2} \\
(\%)\end{array}$ & $\begin{array}{c}E_{0, \min , 2} \\
\left(\mathrm{Im} / \mathrm{m}^{2}=\operatorname{lux}\right)\end{array}$ & $\begin{array}{c}\mathrm{G}_{\mathrm{glob}, \mathrm{o}, \min , 2} \\
\left(\mathrm{~W} / \mathrm{m}^{2}\right)\end{array}$ \\
\hline all-glass façade structures & 5.51 & 13,610 & 127 & 2.28 & 32,895 & 307 \\
\hline S BIPV 100 façade & 4.64 & 16,155 & 151 & 1.92 & 39,060 & 365 \\
\hline$E$ and $W$ BIPV $_{100}$ façades & 4.02 & 18,660 & 174 & 1.82 & 41,200 & 385 \\
\hline all-BIPV 100 façades & 2.12 & 35,380 & 330 & 0.82 & 91,460 & 855 \\
\hline
\end{tabular}

In the final energy demand model, it was assumed that the electrical power of lamps is proportional to the additional light flux that must be emitted by lamps according to hour-by-hour daylight conditions. The highest level of daylight responsive to lighting system control (VIII day-light response, dim, switch off [52]) was assumed. Illuminance dependency factor $F_{C}=0.85$, and absence factor $F_{A}=0.0$ leading to occupancy dependency factor $F_{0}=1.0$ were taken into account. The calculation model of $Q_{1}$ is presented in Appendix $E$. The energy need for lighting is assumed to be equal to the final energy demand for lighting. 


\section{Energy needs of case study all-glass and BIPV $_{100}$ buildings in different climate conditions}

Energy needs were evaluated for the case study all-glass building presented in Chapter 2. Meteorological data in the form of TRY [51] for Stockholm ( $\left.\lambda 18^{\circ} 04^{\prime}, \Phi 59^{\circ} 20^{\prime}\right)$, Ljubljana ( $\left.\lambda 14^{\circ} 28^{\prime}, \Phi 46^{\circ} 06^{\prime}\right)$, and Athens $\left(\lambda 23^{\circ} 43^{\prime}, \Phi 37^{\circ} 59^{\prime}\right)$ were used for the hour-by-hour modelling of energy needs and electricity production. Results are presented for four designs of case study building: for all-glass buildings and for buildings with south BIPV 100 façade, buildings with east and west BIPV 100 façades, and buildings with BIPV 100 façades in all orientations. The results are presented as yearly specific values per square metre of useful area $\left(A_{u}=400 \mathrm{~m}^{2}\right)$ as well as relative according to the reference building which is mechanically ventilated and mechanically cooled.

Total specific energy needs $Q_{\text {needs }}$ of reference case study all-glass buildings (Fig. 7) are in the range from $91.30 \mathrm{kWh} / \mathrm{m}^{2} \mathrm{y}$ in the northern climate (Stockholm), $95.04 \mathrm{kWh} / \mathrm{m}^{2} \mathrm{y}$ in central European climate (Ljubljana) and $142.2 \mathrm{kWh} / \mathrm{m}^{2} \mathrm{y}$ in the Mediterranean climate (Athens). As a consequence of the low thermal transmittance of façade structures and high internal gains in office type buildings, the $Q^{\prime}{ }_{N H}$ are not more than $2.57 \mathrm{kWh} / \mathrm{m}^{2} \mathrm{y}$ (Stockholm) and $0.55 \mathrm{kWh} / \mathrm{m}^{2} \mathrm{y}$ (Ljubljana), meanwhile, the building in Athens almost does not need heating. The $Q^{\prime}{ }_{N C}$ in reference buildings prevails in all climate conditions, with the share between $60 \%\left(60.44 \mathrm{kWh} / \mathrm{m}^{2} \mathrm{y}\right.$, Stockholm) to almost $80 \%\left(116.40 \mathrm{kWh} / \mathrm{m}^{2} \mathrm{y}\right.$, Athens) of total energy needs. Nighttime cooling by ventilation is effective in central European and northern climate conditions as $Q^{\prime}{ }_{N C}$ decrease by $21 \%$ (Stockholm) to $18.5 \%$ (Ljubljana); however, decreases of only $3.8 \%$ could be achieved in Athens. By combining night-time cooling by ventilation with hybrid ventilation, $Q^{\prime}{ }_{N C}$ can be further decreased in all cases: to $48.87 \mathrm{kWh} / \mathrm{m}^{2} \mathrm{y}$ (Stockholm), $49.65 \mathrm{kWh} / \mathrm{m}^{2} \mathrm{y}$ (Ljubljana) and $108.84 \mathrm{kWh} / \mathrm{m}^{2} \mathrm{y}$ (Athens). This is much more in comparison to evaporative cooling, the impact of which can only be observed in hot climate conditions (Athens). Energy needs for mechanical ventilation $Q^{\prime}{ }_{v}$ could be significantly decreased in the case of hybrid ventilation, due to the decreased durations of ventilation system operation: up to $25.4 \%$ in Athens, to 18.5 $\%$ in Ljubljana and $14.5 \%$ in Stockholm. This indicates that hybrid ventilation should be implemented in case study buildings. Energy needs for lighting $Q^{\prime}$ ' have a relatively small share, in the range between $8.4 \%$ (Stockholm), 6.8\% (Ljubljana) to 3.6\% (Athens) of $Q_{\text {needs }}^{\prime}$ due to the large glass façade area. 


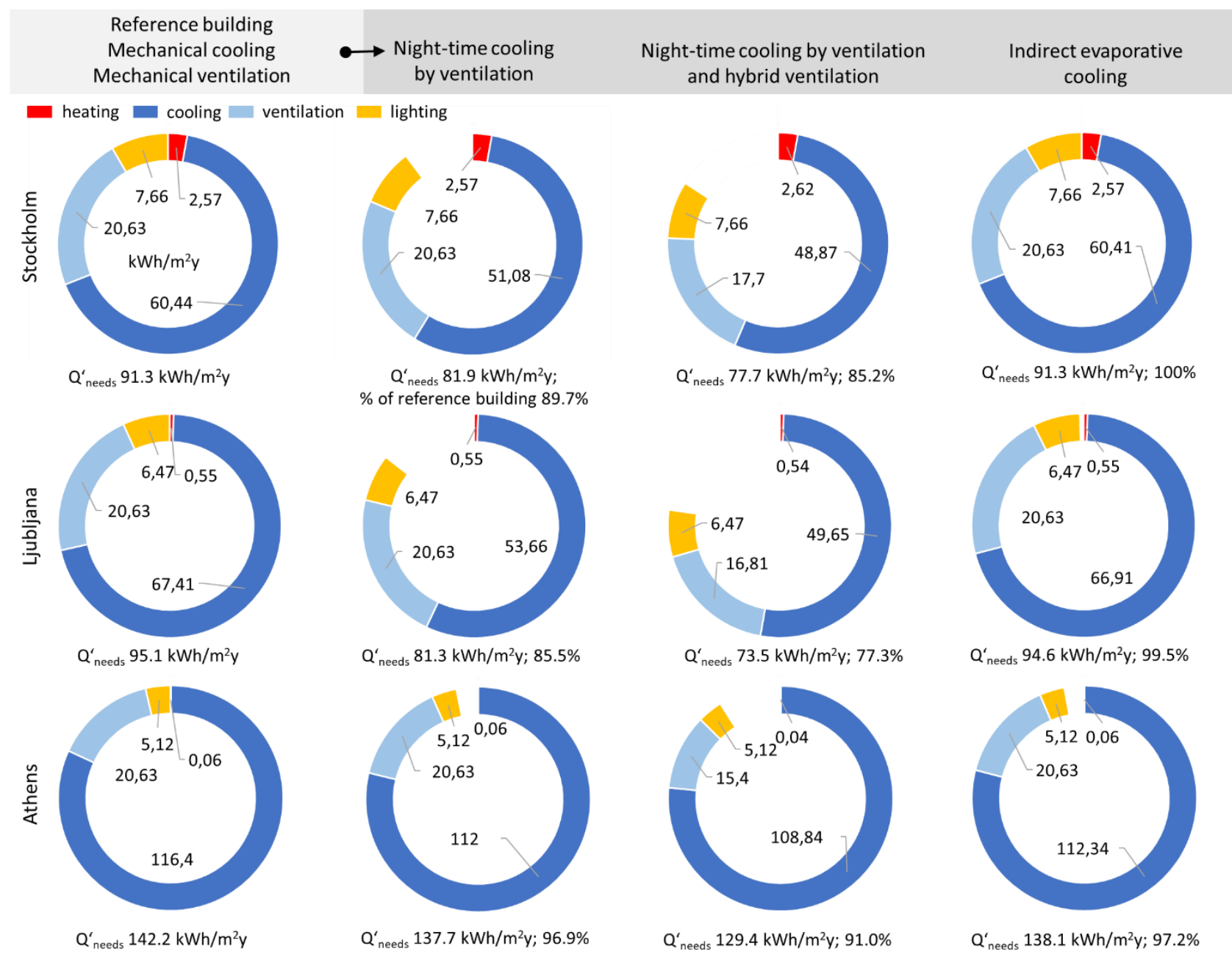

Fig. 7. Yearly specific energy needs $Q^{\prime}{ }_{N H}, Q^{\prime}{ }_{N C}, Q^{\prime}{ }_{v}$, and $Q^{\prime}$ I and total specific energy needs $Q^{\prime}{ }_{\text {needs }}$ in $k W h$ per $\mathrm{m}^{2} \mathrm{y}$ of reference all-glass building and all-glass buildings with different free cooling techniques.

Figure 8 shows the electricity production of BIPV façades and the impacts of such façades on the energy needs for case study examples. Values are normalised per square metre of useful area $A_{u}$ of the building. Meanwhile, electricity production of the south-orientated BIPV $_{100}$ is similar for all sites (between 18.33 $\mathrm{kWh} / \mathrm{m}^{2} \mathrm{y}$ and $22.79 \mathrm{kWh} / \mathrm{m}^{2} \mathrm{y}$ ), due to the increased incident angle of solar irradiation at lower geographic altitudes. Electricity production in the case of an all-BIPV building increases to approximately $58 \mathrm{kWh} / \mathrm{m}^{2} \mathrm{y}$ (Ljubljana and Stockholm) and $71 \mathrm{kWh} / \mathrm{m}^{2} \mathrm{y}$ (Athens). The installation of BIPV on all façades slightly increases the energy need for heating (to $4.67 \mathrm{kWh} / \mathrm{m}^{2} \mathrm{y}$ in Stockholm and $\sim 2 \mathrm{kWh} / \mathrm{m}^{2} \mathrm{y}$ in Ljubljana) but significantly decreases the $Q^{\prime}{ }_{N c}$ : by 67\% (Stockholm), 60.5\% (Ljubljana), and 50\% (Athens). 


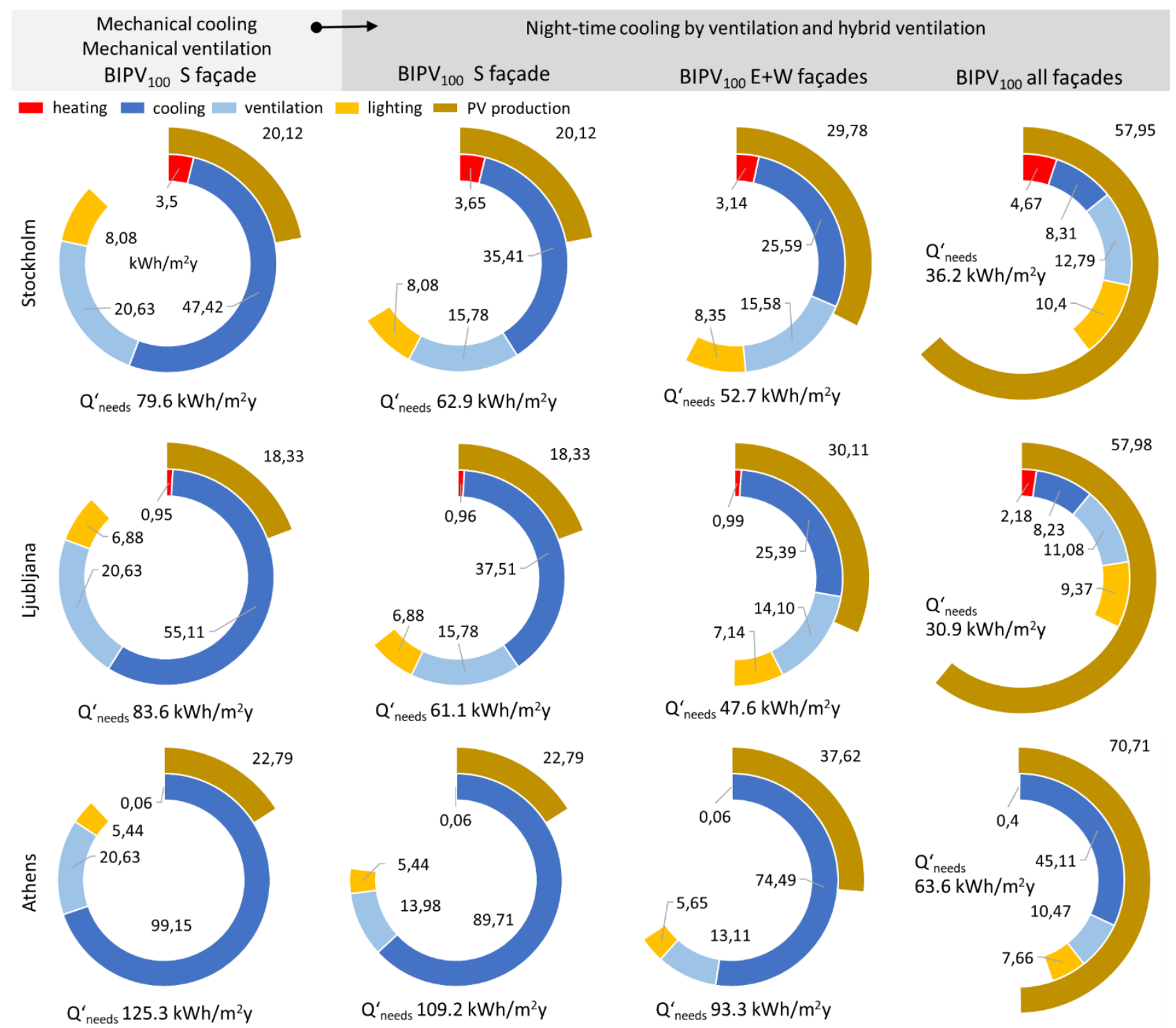

Fig. 8. Yearly specific energy needs $Q^{\prime}{ }_{N H}, Q^{\prime}{ }_{N C}, Q^{\prime}{ }_{v}$, and $Q^{\prime}{ }_{1}$, specific yearly total energy needs $Q^{\prime}$ needs and specific electricity production $\mathrm{E}^{\prime} \mathrm{PV}$ in $\mathrm{kWh}$ per $\mathrm{m}^{2} \mathrm{y}$ for case study buildings with BIPV ${ }_{100}$ façade structures.

Another advantage of BIPV 100 structures is the increased efficiency of night-time cooling by ventilation and hybrid ventilation. In the case of all-BIPV 100 buildings in Stockholm or Ljubljana, $Q^{\prime}$ needs can be decreased by half if night-time cooling by ventilation is applied and by two thirds if hybrid ventilation is also applied. Both techniques are slightly less efficient in the Mediterranean climate; nevertheless, $Q^{\prime}$ needs could be decreased by one third of those of the reference building. BIPV ${ }_{100}$ façade structures reduce $Q^{\prime}{ }_{N C}$ and lower glare risk, but reduce the amount of daylight. Consequently $Q^{\prime}$ । increase: from $7.66 \mathrm{kWh} / \mathrm{m}^{2} \mathrm{y}$ to $10.40 \mathrm{kWh} / \mathrm{m}^{2} \mathrm{y}$ in Stockholm, from $6.47 \mathrm{kWh} / \mathrm{m}^{2} \mathrm{y}$ to $9.77 \mathrm{kWh} / \mathrm{m}^{2} \mathrm{y}$ in Ljubljana and from $5.12 \mathrm{kWh} / \mathrm{m}^{2} \mathrm{y}$ to $7.66 \mathrm{kWh} / \mathrm{m}^{2} \mathrm{y}$ in Athens, comparing reference and all-BIPV ${ }_{100}$ buildings.

\section{7. nZEB metrics of case study all-glass and BIPV ${ }_{100}$ buildings}

The sets of indicators to characterise nZEB buildings are defined in [32], including the definition of weighted delivered and exported energy. Although indicators could be different on the national level, the most common nZEB criteria include yearly specific energy needs for heating $Q^{\prime}{ }_{N H}$ in $\mathrm{kWh} / \mathrm{m}^{2} \mathrm{y}$, yearly specific nonrenewable primary energy (PE) demand $Q_{p, n e n}^{\prime}$ in $\mathrm{kWh} / \mathrm{m}^{2} \mathrm{y}$, and renewable energy ratio RER as a percentage. The specific values are expressed per square metre of the useful floor area of building $A_{u}$. As an example, in Slovenia, nZEB requirements of new non-residential buildings are: $Q^{\prime}{ }_{N H} \leq 25 \mathrm{kWh} / \mathrm{m}^{2} \mathrm{y}, \mathrm{Q}_{\mathrm{p}, \mathrm{n} \text { ren }}^{\prime} \leq 50 \mathrm{kWh} / \mathrm{m}^{2} \mathrm{y}$ and $\mathrm{RER} \geq 50 \%$. 
The specific yearly non-renewable primary energy $Q_{p \text {,nren }}^{\prime}$ demand for the operation of the building is determined at the building envelope as assessment boundary by equation adopted for the case study building:

$Q_{p, \text { nren }}^{\prime}=Q_{f, \text { del,e,grid }}^{\prime} \cdot f_{p, \text { nren,e,grid }}+Q_{f, h, \text { env }}^{\prime} \cdot f_{p, n r e n, h, \text { env }}+E_{P V, \text { del }}^{\prime} \cdot f_{p, \text { nren,e,PV }}-E_{P V, e x p}^{\prime} \cdot f_{p, n r e n, e, g r i d}$

where $Q_{f, d e l, e, g r i d}^{\prime}$ is the specific yearly amount of electricity delivered from the grid, $Q_{f, h, e n v}^{\prime}$ is the specific yearly environmental heat needed for the operation of the heat pump in heating mode, $E^{\prime}{ }_{P V}$,del is the specific yearly produced electricity by $\mathrm{BIPV}_{100}$ façade structures, and $\mathrm{E}_{\mathrm{PV}, \mathrm{exp}}$ is the specific yearly produced electricity exported into the grid. All quantities are expressed in $\mathrm{kWh} / \mathrm{m}^{2} \mathrm{y}$. The delivered energy is weighted by the nonrenewable primary energy factor $f_{n r e n}$ of each energy carrier. Values of $f_{n r e n, e, g r i d}=2.3$ for grid electricity and $f_{p, n r e n, e, P V}=f_{p, n r e n, h, e n v}=0$ for solar energy ( $B I P V_{100}$ structures produced electricity) and environment heat were used in this study [32]. A negative value of $Q_{p, n \text { ren }}^{\prime}$ indicates that the building, due to the export of electricity, also reduces the use of non-renewable sources of other grid-connected consumer.

The renewable energy ratio (RER) is defined as the ratio between yearly renewable primary energy $Q_{p \text {,ren }}^{\prime}$ $\left(\mathrm{kWh} / \mathrm{m}^{2} \mathrm{y}\right)$ and total primary energy $\mathrm{Q}_{\mathrm{p} \text {,tot }}^{\prime}\left(\mathrm{kWh} / \mathrm{m}^{2} \mathrm{y}\right)$ needed for the operation of the building. Both quantities are determined by renewable primary energy factors $\left(f_{p, r e n}\right)$ and total primary energy factors $\left(f_{p, t o t}\right)$ of each energy carrier. Total primary energy factor for the grid electricity 2.5 was assumed. For the environmental heat and solar energy total and renewable primary energy factors are equal to 1 , as both energy carriers are totally renewable. RER is defined by equation:

$$
\mathrm{RER}=\frac{\mathrm{Q}_{\mathrm{p} \text {,ren }}^{\prime}}{\mathrm{Q}_{\mathrm{p}, \text { tot }}^{\prime}} \cdot 100=\frac{\mathrm{Q}_{\mathrm{p}, \mathrm{ren}}^{\prime}}{\mathrm{Q}_{\mathrm{p}, \mathrm{ren}}^{\prime}+\mathrm{Q}_{\mathrm{p}, \mathrm{nren}}^{\prime}} \cdot 100(\%)
$$

In the case of excess on-site electricity produced by BIPV, which is exported to the grid, the value of the RER is $>1$. In this paper, the grid export factor kexp equal to 1 was assumed [32].

Figures 9 to 11 show final energy demand and primary energy balance as well as the RER of the reference case study building with different sizes of BIPV façade structures and different techniques of free cooling. 

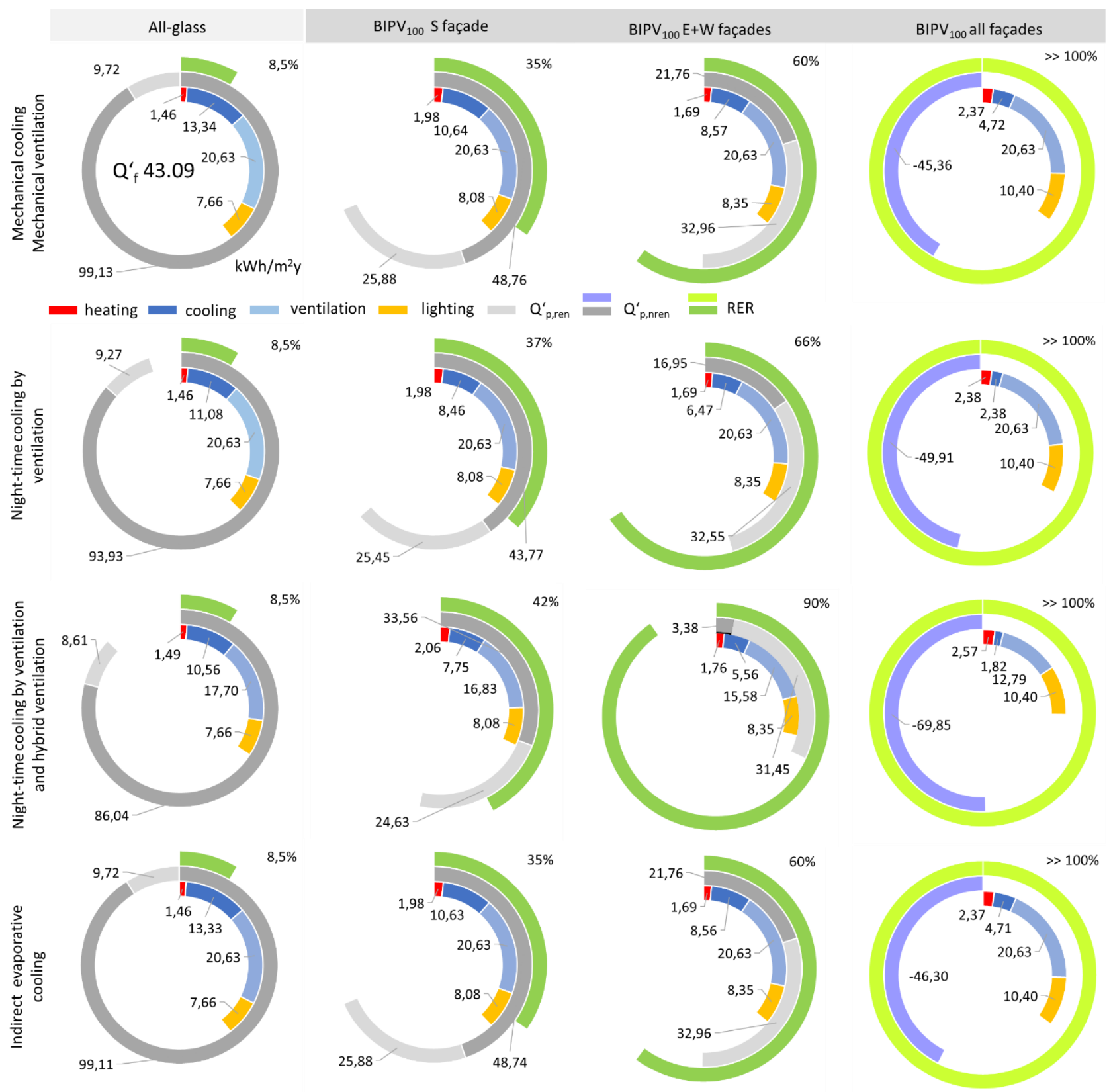

Fig. 9. Specific yearly final energy demand per building utility systems, and nZEB metrics for the case study buildings for Stockholm. 


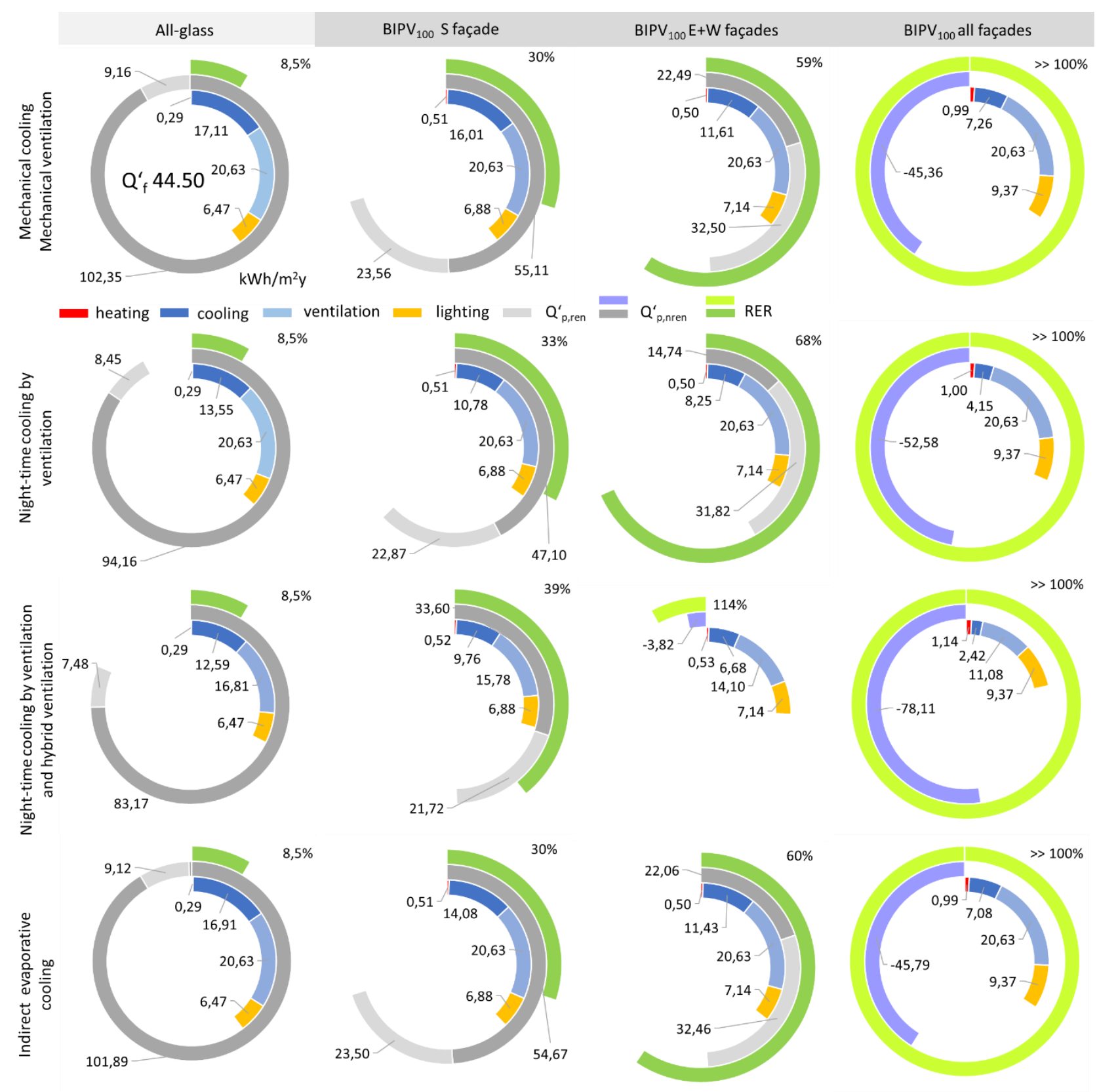

Fig. 10. Specific yearly final energy demand per building utility systems, and nZEB metrics for the case study buildings for Ljubljana. 


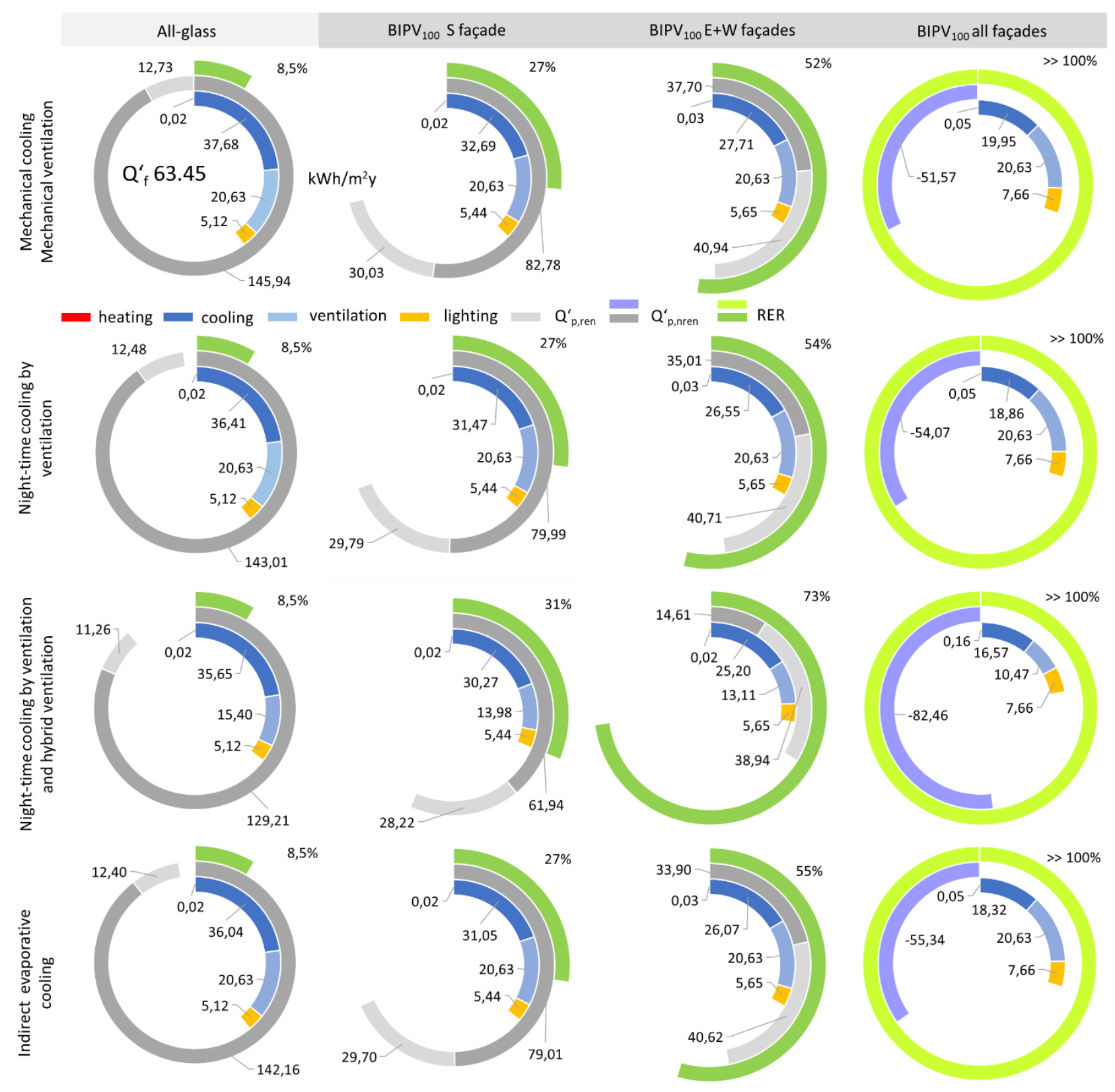

Fig. 11. Specific yearly final energy demand per building utility systems, and nZEB metrics for the case study buildings for Athens.

From Figures 9 to 11, it can be seen that in the case of all-glass buildings specific final energy demand for ventilation and lighting is significantly larger (Stockholm, Ljubljana) or close to (Athens) heating and cooling final energy demand. This leads to the conclusion that all techniques of natural ventilation, as well as natural lighting, must be considered with great emphasis during the design phase. Indirect evaporative cooling noticeably reduces the non-renewable primary energy needed only in the climate conditions of Athens, with an impact similar to night-time cooling by ventilation. The presented results also show that BIPV ${ }_{100}$ façade structures are very effective with regard to specific non-renewable primary energy needs. The value of $Q_{p, n r e n}^{\prime}=50 \mathrm{kWh} / \mathrm{m}^{2}$ can be fulfilled in the reference mechanically ventilated and cooled building in Stockholm with BIPV 100 installed solely on the south façade and similarly for the building in Ljubljana if the night-time cooling by ventilation is implemented. In both cases, additional hybrid ventilation decreases $Q_{p, \text { nren }}^{\prime}$ (33.56 $\mathrm{kWh} / \mathrm{m}^{2} \mathrm{y}$ and $33.60 \mathrm{kWh} / \mathrm{m}^{2} \mathrm{y}$, respectively). BIPV 100 façade structures on more than one façade should be installed in building in Athens; the east and west façades will be sufficient. All-BIPV 100 buildings in all cases are Zero Energy Buildings as $Q_{p, n r e n}^{\prime}$ of the buildings is negative: $\sim 45.4 \mathrm{kWh} / \mathrm{m}^{2} \mathrm{y}$ (Stockholm, Ljubljana) to $51.6 \mathrm{kWh} / \mathrm{m}^{2} \mathrm{y}$ (Athens) in case of a mechanically ventilated and mechanically cooled building. If night-time 
cooling by ventilation and hybrid ventilation is implemented, $Q^{\prime}{ }_{p, n r e n}$ further increases to approximately -70 $\mathrm{kWh} / \mathrm{m}^{2} \mathrm{y}$ (Stockholm), $-78 \mathrm{kWh} / \mathrm{m}^{2} \mathrm{y}$ (Ljubljana) and $-82 \mathrm{kWh} / \mathrm{m}^{2} \mathrm{y}$ (Athens). From Figures 9 to 11 , it can be seen that RER is a more demanding nZEB criterion. Buildings with mechanical cooling and BIPV 100 installed on the south façade of the reference buildings provide between 35\% (Stockholm), 30\% (Ljubljana) and 27\% (Athens) of the RES electricity in total final energy demand. The share significantly increases if BIPV 100 structures are installed on the east and west façades. In this case, the RER $>50 \%$ is provided regardless of the studied climate conditions. If night-time cooling by ventilation and hybrid ventilation is used, RER increases to $73 \%$ (Athens) and $90 \%$ (Stockholm); meanwhile, in such buildings built in Ljubljana, BIPV 100 produce more electricity than the building requires (RER $=114 \%)$. This is the case for all-BIPV ${ }_{100}$ buildings for all analysed sites as well.

\section{Conclusions}

This paper presents research on the compliance of all-glass buildings with nearly Zero Energy Buildings requirements as introduced by the EPBD Recast. Energy needs, primary non-renewable energy needed for the operation of the building, and renewable energy ratios were used as nZEB indicators. The analysed allglass case study buildings are square-shaped office buildings with useful areas of $400 \mathrm{~m}^{2}$ and are built with market available advanced six-pane glass façade structures that can also be made as BIPV façade structures. In the case study, it was assumed that PV cells cover $60 \%$ of the glazed façade structure to enable daylighting and visual contact to the outdoors.

One of the contributions of this study is the procedure developed to integrate the dynamic response model of multi-layer glass and BIPV building façade structures in the form of multi-parametric regression model into a dynamic model of a building's thermal response. The proposed procedure can be used in other applications of glazed façade structures, such as with the non-uniform layout of PV cell, with a ventilated cavity(s), with smart optical properties, or with the pronounced transient thermal response (e.g., glazing with PCM inserts). Energy need for heating is a commonly used indicator of buildings' energy efficiency, based on which energy efficiency class is determined and presented on the (calculated) Energy Label of the building. For the case study all-glass buildings, it was found that regardless of the climate, they can be labelled with A1 class, as specific energy need for heating is in the range from almost zero (Athens) to $2.6 \mathrm{kWh} / \mathrm{m}^{2} \mathrm{y}$ (Stockholm). This also applies to the buildings with all-BIPV façades, for which the energy need for heating is doubled (4.7 $\mathrm{kWh} / \mathrm{m}^{2} \mathrm{y}$, Stockholm). As other energy needs prevail, it can be concluded that total energy needs, which are in the range between 91 to $142 \mathrm{kWh} / \mathrm{m}^{2} \mathrm{y}$, would be a more appropriate nZEB indicator. If nZEB indicators are defined as relative values comparing actual and reference buildings, the weighting factor of reference building energy needs in the range between 0.9 (Athens) and 0.75 (Ljubljana) can be introduced, taking into account free cooling and hybrid ventilation potential. The analysis has shown that BIPV façade structures have significant impact on energy needs, as they are decreased to half in the case of all-BIPV buildings in analysed climate conditions; although the climate in Ljubljana turned out to be the most favourable. This could be an important factor in developing the legislation of the nZEB requirements as well as cost assessment of the BIPV façade structures.

Analysis of final energy demand for operation of the case study buildings shows that nZEB requirements will not hinder the construction of all-glass buildings. Nevertheless, high-performance façade systems (such as the presented multi-layer glass façade structures), use of natural resources (especially for cooling and ventilation), and smart control of building systems, as foreseen in the presented dynamic numerical simulations, should be anticipated. Non-renewable primary energy below $50 \mathrm{kWh} / \mathrm{m}^{2} \mathrm{y}$ (Stockholm and Ljubljana) and around $60 \mathrm{kWh} / \mathrm{m}^{2} \mathrm{y}$ (Athens) could be achieved with BIPV façade structures on the south façade if night-cooling by ventilation is used. In the case of BIPV on two façades ( $E$ and $W$ ), non-renewable primary energy demand close to zero can be achieved in Stockholm and Ljubljana and as low as $15 \mathrm{kWh} / \mathrm{m}^{2} \mathrm{y}$ in Athens in case of the best case natural ventilation scenario.

The RER requirements ( $\geq 50 \%$ ) for nZEB are more difficult to fulfil; nevertheless, they can be achieved by onsite electricity production with BIPV façade structures on any of the analysed locations in case if BIPV is installed on approximately $85 \%$ (Stockholm and Ljubljana) or whole (Athens) of the two, out of the south, the 
east and the west façades, if free cooling and hybrid ventilation is applied. This leads to another important conclusion: that case study all-BIPV buildings are not only Zero Energy Buildings, but also reduce the use of non-renewable energy (by 70 to $80 \mathrm{kWh} / \mathrm{m}^{2} \mathrm{y}$ ) of others to grid-connected users. As such, they can significantly contribute to the sustainability of (smart) cities and to the mitigation of global climate change. In the further research of all-glass buildings, the nZEB indicators considering user adopted parameters of indoor environment could be evaluated. In addition, the regression models that will enable the fast modelling of all-glass buildings in terms of the determination of advanced multi-layer glass to BIPV façade structure ratios according to target nZEB indicators' values would be valuable for building designers.

\section{Acknowledgment}

This work was supported by the European Regional Development Fund, Research and development programmes (TRL 3-6), Programme: 'Sustainable and innovative construction of smart buildings TIGR4smart' (C3330-16-529003). The authors also acknowledge the financial support from the Slovenian Research Agency (research core funding No. P2-0223 (C)).

\section{References}

[1] Directive 2010/31/EU of the European Parliament and of the Council (EPBD recast) on the energy performance of buildings (recast), Official Journal of the European Union, 153/13, 2010.

[2] Energy performance of buildings - Overarching EPB assessment - Part 1: General framework and procedures. ISO 2016.

[3] Directive (EU) 2018/844 of the European Parliament and of the Council, Official Journal of the European Union, 156/75, 2018.

[4] D'Agostino D., Mazarella L.: What is a Nearly zero energy building? Overview, implementation and comparison of definitions. J. Build. Eng., 21 (2019) 200-212, https://doi.org/10.1016/j.jobe.2018.10.019.

[5] Elarga H., Zarrella A., De Carli M.: Dynamic energy evaluation and glazing layer optimization of façade building with innovative integration of PV modules. Energy Build., 111 (2016), 468-478, https://doi.org/10.1016/j.enbuild.2015.11.060.

[6] Asdrubali F., Ballarini I., Corrado V., Evangelisti L., Grazieschi G., Guattari C.: Energy and environmental payback times for an NZEB retrofit. Build. Environ. 147 (2019), 461-472, https://doi.org/10.1016/j.buildenv.2018.10.047.

[7] Pariafsai F.: A review of design consideration in glass buildings. Frontiers of Architectural Research (2016) 5, 171-193, https://doi.org/10.1016/j.foar.2016.01.006.

[8] Jelle B. P., Hynd A., Gustavsen A., Arasteh D., Goudey H., Hart R.: Fenestration of today and tomorrow: A state-of-the-art review and future research opportunities. Sol. Energy Mater. Sol. Cells 96 (2012), 128, https://doi.org/10.1016/j.solmat.2011.08.010.

[9] Hosseini S. M., Mohammadi M., Rosemann A., Schröder T., Lichtenberg J.: A morphological approach for kinetic façade design process to improve visual and thermal comfort: Review. Build. Environ. 153 (2019), 186-204, https://doi.org/10.1016/j.buildenv.2019.02.040.

[10] Lechowska A. A., Schnotale J. A.: Thermal Transmittance of Multi-layer Glazing with Ultrathin Internal Partitions. Proceedings of BS2015 14th Conference of International Building Performance Simulation Association, Hyderabad, India, (2015), 2134-2141.

[11] Medved S., Begelj Ž., Domjan S., Šuklje T., Černe B., Arkar C.: Dynamic thermal response model and energy performance of a multi-layer glass and BIPV façade structures, Energy Build., 188-189 (2019), 239-251, https://doi.org/10.1016/j.enbuild.2019.02.017.

[12] Cuce E.: Experimental and numerical investigation of a novel energy-efficient vacuum glazing technology for low-carbon buildings. Indoor Built Environ. 26(1) (2017), 44-59, https://doi.org/10.1177/1420326X15599188. 
[13] Gao T., Ihara T., Grynning S., Jelle B. P., Gunnarshaug Lien A.: Perspective of aerogel glazings in energy $\begin{array}{lllll}\text { efficient buildings. } & \text { Build. } & \text { Environ. } & 95 & \text { (2016), }\end{array}$ http://dx.doi.org/10.1016/j.buildenv.2015.10.001.

[14] Murano G., Primo E., Corrado V.: The effect of glazing on nZEB performance. Energy Procedia 148 (2018), 320-327, https://doi.org/10.1016/j.egypro.2018.08.084.

[15] Bruno R.: Optimization of glazing systems in Non-Residential buildings: The role of the optical properties of air-conditioned environments. Build. Environ. 126 (2017), 147-160, https://doi.org/10.1016/j.buildenv.2017.09.011.

[16] Lu X., Memari A.M.: Comparative study of Hot Box Test Method using laboratory evaluation of thermal properties of a given building envelope system type. Energy Build. 178 (2018), 130-139, https://doi.org/10.1016/j.enbuild.2018.08.044.

[17] Foucquier A., Robert S., Suard F., Stephan L., Jay A.: State of the art in building modelling and energy performance prediction: A review. Renewable Sustainable Energy Rev. 23 (2013), 272-288, https://doi.org/10.1016/j.rser.2013.03.004.

[18] Li X., Wen J.: Review of building energy modelling for control and operation. Renewable Sustainable Energy Rev. 37 (2014), 517-537, https://doi.org/10.1016/j.rser.2014.05.056.

[19] Hwang R.-L., Shu S.-Y.: Building envelope regulations on thermal comfort in glass façade buildings and energy-saving potential for PMV-based comfort control. Build. Environ. 46 (2011), 824-834, https://doi.org/10.1016/j.buildenv.2010.10.009.

[20] Tzempelikos A., Bessoudo M., Athienitis A. K., Zmeureane R.: Indoor thermal environment conditions neat glazed façades with shading devices - Part II: Thermal comfort simulation and impact of glazing and $\begin{array}{llll}\text { shading properties. } \quad \text { Build. } & \text { (2010), 2517-2525, }\end{array}$ https://doi.org/10.1016/j.buildenv.2010.05.014.

[21] EN 15251:2007 Indoor environment input parameters for design and assessment of energy performance of buildings addressing indoor air quality, thermal comfort, lighting and acoustics. CEN 2017.

[22] Biyik E., Araz M., Hepbasili A., Shahrestani M., Yao R., Shao L., Essah E., Oliveira A. C., Carlo del T., Rico E., Lechon J. L., Andrade L., Mendes A., Atli Y. B.: A key review of building integrated photovoltaic (BIPV) systems. Eng. Sci. Technol. 20 (2017), 833-858, https://doi.org/10.1016/j.jestch.2017.01.009

[23] Shukla A. K., Sudhakar K., Baredar P.: Recent advancement in BIPV product technologies: A review. Energy Build. 140 (2017), 188-195, https://doi.org/10.1016/j.enbuild.2017.02.015.

[24] Zhang T., Wang M., Yang H.: A Review of the Energy Performance and Life-Cycle Assessment of BuildingIntegrated Photovoltaic (BIPV) Systems. Energies 2018, 11, 3157-3168, https://doi.org/10.3390/en11113157.

[25] Zhang W., Lu L.: Overall energy assessment of semi-transparent photovoltaic insulated glass units for building integration under different climate conditions. Renewable Energy, 134 (2019), 818-827, https://doi.org/10.1016/j.renene.2018.11.043.

[26] Jung W., Hong T., Oh J., Kang H., Lee M.: Development of a prototype for multi-function smart window by integrating photovoltaic blinds and ventilation system. Build. Environ. 149 (2019), 366-378, https://doi.org/10.1016/j.buildenv.2018.12.026.

[27] Solgi E., Hamedani Z., Fernando R., Skates H., Orji N.E.: A literature review of night ventilation strategies in buildings. Energy Build. 173 (2018), 337-352, https://doi.org/10.1016/j.enbuild.2018.05.052.

[28] Medved S., Babnik M., Vidrih B., Arkar C.: Parametric study on the advantages of weather-predicted control algorithm of free cooling ventilation systems. Energy 73 (2014), 80-87, https://doi.org/10.1016/j.energy.2014.05.080.

[29] Vidrih B., Arkar C., Medved S.: Generalized model-based predictive weather control for the control of free cooling by enhanced night-time ventilation. Appl. Energy 168 (2016), 482-492, https://doi.org/10.1016/j.apenergy.2016.01.109.

[30] Porumb B., Unguresan P., Tutunaru L. F., Serban A., Balan M.: A review of indirect evaporative cooling technology. Energy Procedia 85 (2016), 461-471, https://doi.org/10.1016/j.egypro.2015.12.228. 
[31] De Antonellis S., Joppolo C. M., Leone C., Liberati P., Milani S.: Indirect evaporative cooling systems: an experimental analysis in summer conditions. Energy Procedia 140 (2017), 467-474, https://doi.org/10.1016/j.egypro.2017.11.158.

[32] ISO 52000-1:2017 Energy performance of buildings - Overarching EPB assessment - Part 1: General framework and procedures. ISO 2017.

[33] TRIMO: Q-Air - New generation of glass façades. https://www.trimo-group.com/en/products/facadesand-walls/q-air, 2019 (accessed 15 January 2019).

[34] Sustainable and innovative construction of smart buildings - TIGR4smart (C3330-16-529003). Final report, supported by European Regional Development Fund, Research and development programmes (TRL 3-6).

[35] Kralj A., Drev M., Žnidaršič M., Černe B., Hafner J., Jelle B. P.: Investigation of 6-pane glazing: Properties and possibilities, Energy Build. 190 (2019), 61-68, https://doi.org/10.1016/j.enbuild.2019.02.033.

[36] Union Glass High-Technology Glass, S.r.l. http://unionglass.it/index.php, 2019 (accessed 15 January 2019).

[37] ISO 18523-1:2016 Energy performance of buildings - Schedule and condition of building, zone and space usage for energy calculation, Part 1 Non-residential buildings. ISO 2016.

[38] WINDOW 7.6. Berkeley Lab, USA,_https://windows.Ibl.gov/software/window, 2018.

[39] PHOENICS 2018, Concentration, Heat \& Momentum (GHAM), UK, 2018.

[40] ISO 6946:2017 Building components and building elements - Thermal resistance and thermal transmittance - Calculation method. ISO 2017.

[41] TRNSYS 17.2 Solar Energy Laboratory, University of Wisconsin-Madison, USA, 2014.

[42] EN 15242:2007 Ventilation of buildings - Calculation methods for the determination of airflow rates in buildings including infiltration. CEN, 2007.

[43] Jayamaha L.: Energy-Efficient Building Systems, McGraw-Hill, New York, 2007.

[44] Feely T.: Wet Versus Dry Cooling Towers, CTI Educational Seminar, February 28, 2001.

[45] EN 15316-6-3:2016 Energy performance of buildings - Method for calculation of system energy requirements and system efficiencies. ISO 2016.

[46] Harvey D. L. D.: A handbook on Low-Energy Buildings and District-Energy Systems. EARTHSCAN, London, 2006.

[47] ISO 7730:2005 Ergonomics of the thermal environment - Analytical determination and interpretation of thermal comfort using calculation of the PMV and PPD indices and local thermal comfort criteria. ISO 2005.

[48] EN 13779:2006 Ventilation of non-residential buildings - Performance requirements for ventilation and room-conditioning systems. ISO 2006.

[49] IDA Indoor Climate and Energy simulation tool 4.8., EQUA Simulation AB., Sweden, 2018.

[50] Littlefair P. J.: Measuring of the luminous efficacy of daylight. Light. Res. Technol., 20 (1988), 177-188, https://doi.org/10.1177/096032718802000405.

[51] Meteonorm - Global meteorological database for solar energy and applied climatology Version 40: edition 2000 Software and data on CD-ROM (ENET--9932704/1). Switzerland.

[52] EN 15193-1:2017 Energy performance of buildings - Energy requirements for lighting - Part 1: Specifications, Module M9. CEN 2017.

\section{Appendices}


A. The coefficients in the regression model $\dot{\mathrm{q}}_{\mathrm{i}, 0^{0}}(\mathrm{t})$ (Eq. 1 ) are:

\begin{tabular}{|c|c|c|c|}
\hline \multicolumn{2}{|c|}{ Multi-layer glass structure } & \multicolumn{2}{c|}{ BIPV $_{100}$ structure } \\
\hline $\mathrm{a}_{1,0}$ & -0.0191 & $\mathrm{a}_{1,0}$ & -0.0071 \\
\hline $\mathrm{a}_{1,1}$ & -0.0304 & $\mathrm{a}_{1,1}$ & -0.0113 \\
\hline $\mathrm{a}_{1,2}$ & -0.0184 & $\mathrm{a}_{1,2}$ & -0.0071 \\
\hline $\mathrm{a}_{1,3}$ & -0.0215 & $\mathrm{a}_{1,3}$ & -0.0109 \\
\hline $\mathrm{a}_{1,4}$ & 0 & $\mathrm{a}_{1,4}$ & 0 \\
\hline $\mathrm{a}_{1,5}$ & -0.0251 & $\mathrm{a}_{1,5}$ & -0.0158 \\
\hline $\mathrm{a}_{2,0}$ & 0.3350 & $\mathrm{a}_{2,0}$ & 0.2500 \\
\hline $\mathrm{a}_{2,1}$ & 0 & $\mathrm{a}_{2,1}$ & 0 \\
\hline $\mathrm{a}_{2,2}$ & 0 & $\mathrm{a}_{2,2}$ & 0 \\
\hline $\mathrm{a}_{2,3}$ & 0 & $\mathrm{a}_{2,3}$ & 0 \\
\hline $\mathrm{a}_{2,4}$ & 0 & $\mathrm{a}_{2,4}$ & 0.0600 \\
\hline $\mathrm{a}_{2,5}$ & 0 & $\mathrm{a}_{2,5}$ & 0 \\
\hline $\mathrm{b}$ & -0.6585 & $\mathrm{~b}$ & -0.3817 \\
\hline
\end{tabular}

B. The incident angle correction factor $\mathrm{k}_{\mathrm{qi}, \mathrm{i}}$ for the six-pane glass façade structure (Fig. 1 ) is equal to:

$$
\mathrm{k}_{\mathrm{qi}}(\mathrm{i})=-3.500 \cdot 10^{-7} \cdot \mathrm{i}^{3}+2.072 \cdot 10^{-5} \cdot \mathrm{i}^{2}-1.638 \cdot 10^{-4} \cdot \mathrm{i}+0.098 \quad(-)
$$

The incident angle correction factor is used for the determination of equivalent solar irradiation on the surface of façade structure $\mathrm{G}_{\mathrm{glob}, \beta, \mathrm{i}}$

$$
\mathrm{G}_{\mathrm{glob}, \beta, \mathrm{i}}(\mathrm{t})=\left(\mathrm{G}_{\mathrm{dir}, \beta}(\mathrm{t}) \cdot \frac{\mathrm{k}_{\mathrm{qi}}(\mathrm{i})}{\mathrm{k}_{\mathrm{qi}}\left(0^{\circ}\right)}+\mathrm{G}_{\mathrm{dif}, \beta}(\mathrm{t}) \cdot \frac{\mathrm{k}_{\mathrm{qi}}\left(55^{\circ}\right)}{\mathrm{k}_{\mathrm{qi}}\left(0^{\circ}\right)}\right) \quad\left(\mathrm{W} / \mathrm{m}^{2}\right)
$$

The equivalent solar irradiation is taken into account in Eq. 1 at each time step to determine the actual heat flux at the inner surface of multi-layer or BIPV façade structure $q_{i}(t)$.

C. The determination of infiltration air flow rate in case of natural cooling by night-time ventilation was done according to the methodology in [42]; the tilt angle correction factor for a bottom-hung tilted window is:

$$
\mathrm{C}_{\mathrm{k}}(\alpha)=2.60 \cdot 10^{-7} \cdot \alpha^{3}-1.19 \cdot 10^{-4} \cdot \alpha^{2}+1.86 \cdot \alpha(-)
$$

where $\alpha$ is tilt angle in ${ }^{\circ}$. Infiltration airflow is equal to:

$$
\dot{\mathrm{V}}_{\text {inf }}=3.6 \cdot 500 \cdot \mathrm{A}_{\mathrm{OW}} \cdot \sqrt[2]{0.01+0.001 \cdot \mathrm{v}_{\mathrm{w}}^{2}+0.0035 \cdot \mathrm{H}_{\mathrm{w}} \cdot\left|\mathrm{T}_{\mathrm{i}}-\mathrm{T}_{\mathrm{e}}\right|} \quad\left(\mathrm{m}^{3} / \mathrm{h}\right)
$$

where $A_{o w}$ is the open area of the tilted façade structure in $m^{2}$ calculated as $C_{k}(\alpha) \times A_{w}, A_{w}$ is the openable area of the façade structure in $\mathrm{m}^{2}, \mathrm{H}_{\mathrm{w}}$ is height of openable façade structures in $\mathrm{m}, \mathrm{v}_{\mathrm{w}}$ wind speed $10 \mathrm{~m}$ above the ground in $\mathrm{m} / \mathrm{s}$, and $\mathrm{T}_{i}$ and $\mathrm{T}_{\mathrm{e}}$ are air temperatures of indoor and outdoor air in ${ }^{\circ} \mathrm{C}$.

D. The model of HP/cooling engine coefficient of performance for heating and cooling mode:

$$
\begin{gathered}
\mathrm{COP}_{\mathrm{h}}=\eta_{\mathrm{h}}\left(\frac{\mathrm{T}_{\mathrm{e}}-\Delta \mathrm{K}}{\left(\mathrm{T}_{\mathrm{h}, \mathrm{w}}+\Delta \mathrm{K}\right)-\left(\mathrm{T}_{\mathrm{e}}-\Delta \mathrm{K}\right)}+1\right) \quad(-) \\
\mathrm{COP}_{\mathrm{c}}=\eta_{\mathrm{c}}\left(\frac{\mathrm{T}_{\mathrm{c}, \mathrm{w}}-3 \mathrm{~K}}{\left(\mathrm{~T}_{\mathrm{e}}+\Delta \mathrm{K}\right)-\left(\mathrm{T}_{\mathrm{c}, \mathrm{w}}-\Delta \mathrm{K}\right)}\right) \quad(-)
\end{gathered}
$$

Where $\eta_{\mathrm{h}}$ and $\eta_{\mathrm{c}}$ are the Carnot efficiencies of the heat pump in heating and cooling mode (default values 0.50 and 0.35$), T_{e}$ is the outdoor air temperature, $T_{h, w}$ and $T_{c, w}$ are the temperatures of heating and cooling water (default values $50^{\circ} \mathrm{C}$ and $7^{\circ} \mathrm{C}$ ), and $\Delta \mathrm{K}$ is the empirical design temperature difference in the evaporator and condenser (default $3 \mathrm{~K}$ ).

E. The minimum outdoor illuminance $\mathrm{E}_{\mathrm{e}, \mathrm{min}}$ and minimum solar irradiation $\mathrm{G}_{\mathrm{glob}, \mathrm{o}, \mathrm{min}}$ at which daylight will provide illumination $E_{d}$ of working plane of each zone (i) is determined by equations:

$$
E_{e . m i n, i}=\frac{E_{d}}{D_{a}, i} \text { (lux) and } G_{\text {glob,o,min,i }}=\frac{E_{e . m i n, i}}{K_{\text {s.glob }}}\left(\frac{\operatorname{lm}}{m^{2}} \cdot \frac{W}{l m}=\frac{W}{m^{2}}\right)
$$


where $\mathrm{DF}_{\mathrm{avy}}$ is expressed as a decimal value. Hourly final energy needs for lighting is determined by the equation:

$$
\begin{gathered}
\dot{\mathrm{Q}}_{\mathrm{l}}(\mathrm{t})=\sum_{\mathrm{i}=1}^{2} \frac{\mathrm{E}_{\mathrm{d}, \mathrm{i}}-\mathrm{G}_{\mathrm{glob}, \mathrm{o}}(\mathrm{t}) \cdot \mathrm{K}_{\mathrm{s}, \mathrm{glob}} \cdot \mathrm{DF}_{\mathrm{avg}, \mathrm{i}}}{\mathrm{K}_{\mathrm{l}}} \cdot \mathrm{F}_{\mathrm{C}} \cdot \mathrm{F}_{\mathrm{O}} \cdot \mathrm{F}_{\mathrm{SCH}, \mathrm{t}} \cdot \mathrm{A}_{\mathrm{zone}, \mathrm{i}}(\mathrm{W}) \\
\text { if } \dot{\mathrm{Q}}_{\mathrm{f}, \mathrm{L}}(\mathrm{t}) \leq 0 \text { then } \dot{\mathrm{Q}}_{\mathrm{f}, \mathrm{L}}(\mathrm{t})=0
\end{gathered}
$$

$\mathrm{F}_{\mathrm{sCH}, \mathrm{t}}$ is schedule factor (equal to 1 if the building is occupied; otherwise, $\mathrm{F}_{\mathrm{sCH}, \mathrm{t}}$ is 0 ) and $\mathrm{A}_{\text {zone, }}$ is $\mathrm{i}$-th zone floor area. 